\title{
Evaluation of discrepancy between measured and modelled oxidized mercury species
}

\author{
G. $K^{1}{ }^{1}$, A. Ryzhkov ${ }^{2}$, A. Dastoor ${ }^{3}$, J. Narayan ${ }^{4}$, A. Steffen ${ }^{4}$, P. A. Ariya ${ }^{5}$, and L. Zhang ${ }^{4}$ \\ ${ }^{1}$ McGill University, Atmospheric and Oceanic Sciences, 801 Sherbrooke Street West, Montreal, QC, H3A 2K6, Canada \\ ${ }^{2}$ Independent Researcher, 4998 Maisonneuve West, Westmount, QC, H3Z 1N2, Canada \\ ${ }^{3}$ Air Quality Research Division, Environment Canada, 2121 Transcanada Highway, Dorval, QC, H9P 1J3, Canada \\ ${ }^{4}$ Air Quality Research Division, Environment Canada, 4905 Dufferin Street, Toronto ON M3H 5T4, Canada \\ ${ }^{5}$ McGill University, Atmospheric and Oceanic Sciences and Chemistry, 805 Sherbrooke Street West, Montreal, \\ QC, H3A 2K6, Canada
}

Correspondence to: A. Dastoor (ashu.dastoor@ec.gc.ca)

Received: 29 May 2012 - Published in Atmos. Chem. Phys. Discuss.: 12 July 2012

Revised: 16 April 2013 - Accepted: 18 April 2013 - Published: 14 May 2013

\begin{abstract}
L. Zhang et al. (2012), in a recent report, compared model estimates with new observations of oxidized and particulate mercury species $\left(\mathrm{Hg}^{2+}\right.$ and $\left.\mathrm{Hg}_{\mathrm{p}}\right)$ in the Great Lakes region and found that the sum of $\mathrm{Hg}^{2+}$ and $\mathrm{Hg}_{\mathrm{p}}$ varied between a factor of 2 to 10 between measurements and model. They suggested too high emission inputs as $\mathrm{Hg}^{2+}$ and too fast oxidative conversion of $\mathrm{Hg}^{0}$ to $\mathrm{Hg}^{2+}$ and $\mathrm{Hg}_{\mathrm{p}}$ as possible causes. This study quantitatively explores measurement uncertainties in detail. These include sampling efficiency, composition of sample, interfering species and calibration errors. Model (Global/Regional Atmospheric Heavy Metals Model - GRAHM) sensitivity experiments are used to examine the consistency between various $\mathrm{Hg}$ measurements and speciation of $\mathrm{Hg}$ near emission sources to better understand the discrepancies between modelled and measured concentrations of $\mathrm{Hg}^{2+}$ and $\mathrm{Hg}_{\mathrm{p}}$. We find that the ratio of $\mathrm{Hg}^{0}, \mathrm{Hg}^{2+}$ and $\mathrm{Hg}_{\mathrm{p}}$ in the emission inventories, measurements of surface air concentrations of oxidized $\mathrm{Hg}$ and measurements of wet deposition are currently inconsistent with each other in the vicinity of emission sources. Current speciation of $\mathrm{Hg}$ emissions suggests higher concentrations of $\mathrm{Hg}^{2+}$ in air and in precipitation near emission sources; however, measured air concentrations of $\mathrm{Hg}^{2+}$ and measured concentrations of $\mathrm{Hg}$ in precipitation are not found to be significantly elevated near emission sources compared to the remote regions. The averaged unbiased root mean square error (RMSE) between simulated and observed concentrations of $\mathrm{Hg}^{2+}$ is found to be reduced by $42 \%$ and for $\mathrm{Hg}_{\mathrm{p}}$ re-
\end{abstract}

duced by $40 \%$ for 21 North American sites investigated, when a ratio for $\mathrm{Hg}^{0}: \mathrm{Hg}^{2+}: \mathrm{Hg}_{\mathrm{p}}$ in the emissions is changed from $50: 40: 10$ (as specified in the original inventories) to $90: 8: 2$. Unbiased RMSE reductions near emissions sources in the eastern United States and Canada are found to be reduced by up to $58 \%$ for $\mathrm{Hg}^{2+}$. Significant improvement in the model simulated spatial distribution of wet deposition of mercury in North America is noticed with the modified $\mathrm{Hg}$ emission speciation. Measurement-related uncertainties leading to lower estimation of $\mathrm{Hg}^{2+}$ concentrations are $86 \%$. Uncertainties yielding either to higher or lower $\mathrm{Hg}^{2+}$ concentrations are found to be $36 \%$. Finally, anthropogenic emission uncertainties are $106 \%$ for $\mathrm{Hg}^{2+}$. Thus it appears that the identified uncertainties for model estimates related to mercury speciation near sources, uncertainties in measurement methodology and uncertainties in emissions can close the gap between modelled and observed estimates of oxidized mercury found in L. Zhang et al. (2012). Model sensitivity simulations show that the measured concentrations of oxidized mercury, in general, are too low to be consistent with measured wet deposition fluxes in North America. Better emission inventories (with respect to speciation), better techniques for measurements of oxidized species and knowledge of mercury reduction reactions in different environments (including in-plume) in all phases are needed for improving the mercury models. 


\section{Introduction}

Knowledge of the relationship between emission and deposition of atmospheric mercury is critical for the development of policies to reduce the levels of mercury in the environment, but mercury chemistry, including its sources and sinks, is still not fully understood. While most mercury is present in the atmosphere in elemental form $\left(\mathrm{Hg}^{0}\right)$, other oxidized mercury species (mostly as $\mathrm{Hg}^{2+}$ ) contribute significantly to overall processes due to their reactivity with other atmospheric species and constituents (Schroeder and Munthe, 1998). Both elemental and oxidized mercury species in gaseous and particulate forms are emitted from anthropogenic sources into the atmosphere, while only gaseous elemental mercury $\left(\mathrm{Hg}^{0}\right)$ originates from terrestrial and oceanic (biogenic) sources (Lindberg and Stratton, 1998). Gaseous oxidized mercury $\left(\mathrm{Hg}^{2+}\right)$ is further produced from slow oxidation of elemental mercury in gas and aqueous phases (Liu et al., 2010). Low solubility and a comparatively long atmospheric lifetime of six months to one year results in global transport and slow deposition to the earth's surface of $\mathrm{Hg}^{0}$ (Schroeder and Munthe, 1998). $\mathrm{Hg}^{2+}$ and particle-bound mercury $\left(\mathrm{Hg}_{\mathrm{p}}\right)$ species, on the other hand, are removed by precipitation and surface uptake (dry deposition) at a much faster rate (i.e. within one to two weeks), making these species regional pollutants. Due to their solubility and reactivity, oxidized and particulate species are subject of a considerable body of research despite significantly lower concentrations $\left(\mathrm{ng} \mathrm{m}^{-3}\right.$ for $\mathrm{Hg}^{0}$ vs. $\mathrm{pg} \mathrm{m}^{-3}$ levels for $\mathrm{Hg}^{2+} / \mathrm{Hg}_{\mathrm{p}}$; e.g. see Engle et al., 2010; Huang et al., 2010; Yatavelli et al., 2006; Poissant et al., 2005; Liu et al., 2011).

Many of the factors determining concentration changes of mercury species in the atmosphere remain poorly explored or unknown. The ratios of the emissions of $\mathrm{Hg}^{0}, \mathrm{Hg}^{2+}$ and $\mathrm{Hg}_{\mathrm{p}}$ species at the anthropogenic sources and oxidationreduction processes in the emission plume and atmosphere determine the speciation of $\mathrm{Hg}$ in the atmosphere (Seigneur et al., 2004). While atmospheric mercury reactions have been studied extensively, the impact of in-plume reactions on speciation is less known. A modelling study suggests reduction of $\mathrm{Hg}^{2+}$ in the plume by $\mathrm{SO}_{2}$ (Lohmann et al., 2006), but there are very few and contradictory in-plume experimental studies that neither confirm nor deny the possibility of inplume reduction with certainty (Edgerton et al., 2006; Landis et al., 2009; Kolker et al., 2010; Deeds et al., 2013). As a consequence observations for oxidized and particulate mercury are required to determine the actual ratio of mercury species that will subsequently undergo tropospheric reactions.

For $\mathrm{Hg}_{\mathrm{p}}$, aerosol size distribution and composition are the major driver for processes involving particles, clusters and heterogeneous chemistry. Besides established aerosol research, the chemistry and properties of atmospheric ultrafine particles (UFPs, $<100 \mathrm{~nm}$, also called nanoaerosols) have received growing attention in recent years (Justino et al., 2011). While it represents a small mass fraction of over- all aerosol, its surface area and number density are considerable, and, therefore, UFPs are involved in heterogeneous chemical reactions and the formation of cloud condensation nuclei. While aggregates of UFPs into clusters are greater in size, their properties are still distinct from aerosol particles of similar size, featuring a larger surface area for chemical reactions (Maynard and Aitken, 2007). A primary source of UFP is combustion, as hot exhaust gases mix with cooler air, and photochemically driven gas-to-particle formation processes. Detailed studies specific for mercury are not yet available to the authors' knowledge.

Since the mercury deposition-characteristics highly depend on speciation, accurate determination of mercury fractions is key to the precise estimation of deposition near and away from the sources. An extensive network of mercury monitoring stations has been established in North America in recent years. The Mercury Deposition Network (MDN) monitors total mercury $\mathrm{Hg}_{t}$ concentrations from wet deposition over a large part of the continental US supplemented by Canadian stations (Prestbo and Gay, 2009). Measurement results agree reasonably well with model output data, typically within a factor of 2 , because of a good correlation with precipitation data and the fact that no mercury fraction analysis is performed (Ryaboshapko et al., 2007b). The MDN network has recently been supplemented by Atmospheric Mercury Network (AMNet) with the goal to provide fraction measurements to assess the impact of oxidized and particulate mercury species (Fitzgerald, 1995). Operational parameters and data management of AMNet are evolving with the goal of harmonizing protocols for better comparability (Steffen et al., 2012). AMNet has been providing oxidized and particulate mercury data in a structured fashion since 2009. Data analysis and model comparisons in this and previous studies rely mainly on AMNet data sets or pre-2009 data sets recorded at the same sites before the network was formally established.

The Tekran system is the most commonly employed analysis system for the determination of $\mathrm{Hg}^{0}, \mathrm{Hg}^{2+}$ and $\mathrm{Hg}_{\mathrm{p}}$ for AMNet and Canadian measurement sites. It combines automatic unsupervised long-term measurements with high sensitivity and field-based analysis (NAD Program: Atmospheric Mercury Network Site Operations Manual Version $1.0,2011)$. Selective sample collection regimes are used to collect $\mathrm{Hg}^{0}, \mathrm{Hg}^{2+}$ and $\mathrm{Hg}_{\mathrm{p}}$ from the atmosphere. Since the system is the work horse for atmospheric mercury detection, its analytical performance has been well studied and a number of methodological uncertainties and limitations were identified (e.g. Swartzendruber et al., 2009; Slemr et al., 2009; Lyman et al., 2010). These include calibration nonlinearity at low concentrations, and losses due to interference of oxidants and incomplete capture of $\mathrm{Hg}^{2+}$. We aim to present a cumulative estimate for these uncertainties to better understand the variability of measurements.

Table 1 illustrates recent measurements of $\mathrm{Hg}^{2+}$ and $\mathrm{Hg}_{\mathrm{p}}$ from different locations in the Northern Hemisphere. $\mathrm{Hg}^{2+}$ 
and $\mathrm{Hg}_{\mathrm{p}}$ concentrations are often close to the instrument method detection limit (MDL; $\mathrm{Hg}^{2+}: 0.5-6.2 \mathrm{pg} \mathrm{m}^{-3}, \mathrm{Hg}_{\mathrm{p}}$ : $1.10-4 \mathrm{pg} \mathrm{m}^{-3}$; for details see Table 3 ). Both species concentrations are found at similar orders of magnitude and make up less than $1 \%$ of total atmospheric mercury. Studies aim to assess the regional impact associated with their short lifetimes (Weiss-Penzias et al., 2007). Observation data show considerable variation and concentration of up to $89 \pm 150 \mathrm{pg} \mathrm{m}^{-3}$ for $\mathrm{Hg}^{2+}$ in Baltimore, $\mathrm{MD}$, and $80.8 \pm 283 \mathrm{pg} \mathrm{m}^{-3}$ near a cement plant in the San Francisco Bay Area, CA (see Table 1). The average $\mathrm{Hg}^{2+} / \mathrm{Hg}_{\mathrm{p}}$ ratio from the data in Table 1 is $0.85 \pm 0.38$ (mean \pm standard deviation of calculated ratio for all ratio data $<3$ ), illustrating the importance of particulate mercury species in atmospheric processes.

Until now, it was not possible to perform a comprehensive evaluation of $\mathrm{Hg}^{2+}$ and $\mathrm{Hg}_{\mathrm{p}}$ species simulated by the $\mathrm{Hg}$ models, mostly because of a lack of a sufficient body of measurement data. Recently, AMNet results were used in a comparative study of model estimates (L. Zhang et al., 2012). In brief, outputs from three different atmospheric mercury models including Environment Canada's mercury model GRAHM (Global/Regional Atmospheric Heavy Metals Model) were compared to AMNet measurement results from 15 sites in the Great Lakes region. Model results of $\mathrm{Hg}^{2+}$ and $\mathrm{Hg}_{\mathrm{p}}$ at the 15 sites were overestimated by a factor of 2-10 for the sum of $\mathrm{Hg}^{2+}$ and $\mathrm{Hg}_{\mathrm{p}}$. Zhang et al. (2012) provide several hypotheses for this discrepancy: (1) too high emission inputs; (2) too fast oxidative conversion of $\mathrm{Hg}^{0}$ to $\mathrm{Hg}^{2+}$ and $\mathrm{Hg}_{\mathrm{p}}$; and (3) too low dry deposition velocities. While deposition velocities are discussed in some detail and not identified as the main source for the observed discrepancy, the authors suggest further investigation that led to the overestimation of the dry deposition results.

Currently, the modelling estimates of dry deposition velocities of mercury species are not constrained with observations; therefore it is difficult to use the limited measurements of dry deposition fluxes of mercury to evaluate the ambient concentrations of oxidized mercury. Moreover, measured dry deposition estimates are considered highly uncertain. Comparatively, ambient concentrations of $\mathrm{Hg}^{0}$ and wet deposition fluxes of mercury have been extensively measured and are considered more reliable for constraining the models. Therefore, we make use of the measured wet deposition fluxes to constrain and evaluate the uncertainties in model-estimated ambient concentrations of oxidized mercury species in addition to the recent measurements of the oxidized mercury concentrations.

The presented study strives to analyse reported discrepancies between observed $\mathrm{Hg}^{2+}$ and $\mathrm{Hg}_{\mathrm{p}}$ concentrations and explores the seeming disconnect with mercury wet deposition by means of a detailed analysis of uncertainties for measurements, highlighting chemistry knowledge gaps and using model sensitivity experiments.

\section{Materials and methods}

\subsection{Model description}

GRAHM is an Eulerian model built on top of Environment Canada's Global Environmental Multiscale-Global Deterministic Prediction System (Côté et al., 1998a, b). Meteorological and mercury processes are fully integrated in the GRAHM online chemical transport model. Mercury species described are $\mathrm{Hg}^{0}, \mathrm{Hg}^{2+}$ and $\mathrm{Hg}_{\mathrm{p}}$. At each time step, mercury emissions are added to the atmospheric model concentrations, the meteorological processes are simulated, and the atmospheric mercury species are transported, transformed chemically and deposited. GRAHM has been seen to perform well in past studies (Ryaboshapko et al., 2007a, b; Dastoor et al., 2008; Durnford et al., 2010). Model sensitivity runs were conducted using the same configuration of GRAHM as used in the study by L. Zhang et al. (2012) to explore the main reasons for the discrepancy between modelled and measured oxidized mercury concentrations.

The gaseous oxidation of mercury by $\mathrm{O}_{3} / \cdot \mathrm{OH}$, with a temperature-dependent rate constant for $\mathrm{O}_{3}$ oxidation following Hall (1995) and for 'OH oxidation following Pal and Ariya (2004) (and Sommar et al., 2001), occurs throughout the atmosphere. The gaseous oxidation of mercury by halogens, including atomic and molecular chlorine and bromine as well as bromine oxide, occurs in the Arctic and marine boundary layer using reaction rate constants from Ariya et al. (2002), Raofie and Ariya (2003) and Donohoue et al. (2006). Mercury is reduced in the aqueous phase photochemically and by the sulfite anion using rate constants from Xiao et al. (1995) and Van Loon et al. (2000). The reduction processes in GRAHM are insignificant, and their elimination in the model has no impact on the simulated $\mathrm{Hg}^{0}$ distribution or wet deposition. Holmes et al. (2010) noted that atmospheric reduction is not required to explain any of the major features of the global mercury cycle until better constraints on $\mathrm{Hg}^{0}$ oxidation rates are available. Dry deposition in GRAHM is based on the resistance approach (Zhang, 2001; Zhang et al., 2003). In the wet deposition scheme, $\mathrm{Hg}^{0}$ and $\mathrm{Hg}^{2+}$ are partitioned between cloud droplets and air using a temperature-dependent Henry's law constant. We use the global anthropogenic mercury emission fields produced by AMAP for 2005 (Pacyna et al., 2010). Non-anthropogenic terrestrial and oceanic emissions of $\mathrm{Hg}^{0}$ in the model are based on the global mercury budget of Mason (2009). Horizontal resolution of the model runs is $1^{\circ} \times 1^{\circ}$ latitude/longitude and in the vertical model has 28 layers up to $10 \mathrm{hPa}$.

Gas phase oxidation with $\mathrm{O}_{3}$, $\mathrm{OH}$ radical and halogens (mainly $\mathrm{Br}$ ) have been suggested as potential oxidants of $\mathrm{Hg}^{0}$ in the atmosphere (Subir et al., 2012). However, the exact reaction mechanisms, products and reaction rate coefficients are not known, and the relative importance of these reactions in the atmosphere is controversial. Using theoretical work, 
Table 1. Summary of literature data of $\mathrm{Hg}^{0}, \mathrm{Hg}^{2+}$ and $\mathrm{Hg}_{\mathrm{p}}$ measurements published from 2002 to 2010. All concentrations in pg $\mathrm{m}^{-3}$. Uncertainties, where available, and significant figures are as reported by authors. $\mathrm{Hg}^{2+} / \mathrm{Hg}_{\mathrm{p}}$ ratios were calculated from reported speciation data. " " indicates $\mathrm{Hg}^{2+} / \mathrm{Hg}_{\mathrm{p}}$ estimations based on concentration ranges reported by original authors.

\begin{tabular}{|c|c|c|c|c|c|}
\hline $\mathrm{Hg}^{0}$ & $\mathrm{Hg}^{2+}$ & $\mathrm{Hg}_{\mathrm{p}}$ & $\mathrm{Hg}^{2+} / \mathrm{Hg}_{\mathrm{p}}$ & Approximate Location & Reference \\
\hline $1.62 \pm 0.3$ & $8 \pm 13$ & $8 \pm 25$ & 1.0 & Ny-Ålesund, Svalbard & Steen et al. (2011) \\
\hline $1.73 \pm 0.36$ & $3.2 \pm 1.7$ & $1.0 \pm 0.7$ & 3.2 & Arctic & Sommar et al. (2010) \\
\hline 9.6 & 19 & 47 & 0.40 & Idrijca, Slovenia & Kocman and Horvat (2010) \\
\hline 1.62 & 5.18 & 9.15 & 0.57 & Devil's Lake, WI & Engle et al. (2010) \\
\hline 1.61 & 2.0 & 2.2 & 0.91 & Lostwood Refuge, ND & Engle et al. (2010) \\
\hline 1.27 & 1.8 & 4.6 & 0.39 & Shenandoah Park, VA & Engle et al. (2010) \\
\hline 2.32 & 37.5 & 25.4 & 1.47 & East St. Louis, IL & Engle et al. (2010) \\
\hline 2.52 & 10.1 & 11.8 & 0.86 & Milwaukee, WI & Engle et al. (2010) \\
\hline 1.64 & 3.8 & 2.8 & 1.36 & Weeks Bay, AL & Engle et al. (2010) \\
\hline 1.45 & 3.3 & 2.3 & 1.43 & Charleston, SC & Engle et al. (2010) \\
\hline 1.54 & 2.7 & 4.0 & 0.68 & Cape Cod, MA & Engle et al. (2010) \\
\hline 1.4 & 1.5 & 1.2 & 1.3 & Puerto Rico & Engle et al. (2010) \\
\hline 1.49 & 4.08 & 6.57 & 0.62 & Rochester, NY & Huang et al. (2010) \\
\hline $1.3-1.4$ & $0.6-0.8$ & $2.6-5.0$ & 0.18 & Central Wisconsin & Kolker et al. (2010) \\
\hline $1.5-4.0$ & $0-60$ & $0-80$ & $\sim 0.75$ & Houston, TX & Brooks et al. (2010) \\
\hline $2.5 \pm 1.4$ & $15.5 \pm 54.9$ & $18.1 \pm 61.0$ & 0.86 & Detroit, MI & Liu et al. (2010) \\
\hline $1.6 \pm 0.6$ & $3.8 \pm 6.6$ & $6.1 \pm 5.5$ & 0.62 & Dexter, MI & Liu et al. (2010) \\
\hline 1.73 & 12.1 & 2.3 & 5.26 & Mt. Front Lulin, Taiwan & Sheu et al. (2010) \\
\hline $2.20 \pm 1.39$ & $25.2 \pm 52.8$ & $80.8 \pm 283$ & 0.31 & Cement plant, CA & Rothenberg et al. (2010b) \\
\hline $1.76 \pm 0.88$ & $2.58 \pm 1.28$ & $3.17 \pm 3.20$ & 0.81 & Moffett, CA & Rothenberg et al. (2010a) \\
\hline $2.37 \pm 1.26$ & $14.5 \pm 30.2$ & $7.99 \pm 6.74$ & 1.81 & Calero, CA & Rothenberg et al. (2010a) \\
\hline $2.25 \pm 0.04$ & $8.93 \pm 0.31$ & $8.21 \pm 0.39$ & 1.09 & Elizabeth, NJ & Aucott et al. (2009) \\
\hline $2.25 \pm 0.02$ & $10.73 \pm 0.45$ & $6.04 \pm 0.30$ & 1.78 & New Brunswick, NJ & Aucott et al. (2009) \\
\hline $4.5 \pm 3.1$ & $14.2 \pm 13.2$ & $21.5 \pm 16.4$ & 0.66 & Toronto, ON & Song et al. (2009) \\
\hline $1.2-1.5$ & $26,45,86$ & $6,5,10$ & $4.3,9,8.6$ & Nevada & Weiss-Penzias et al. (2009) \\
\hline $7.2 \pm 4.8$ & $62 \pm 64$ & $187 \pm 300$ & 0.33 & Mexico City, Mexico & Rutter et al. (2009) \\
\hline $1.6 \pm 0.3$ & $4.0 \pm 7.5$ & $2.7 \pm 3.4$ & 1.48 & Weeks Bay, AL & Engle et al. (2008) \\
\hline $3.58 \pm 1.78$ & 65 & 77 & 0.84 & Mt. Changbai, NE China & $\begin{array}{l}\text { Wan et al. (2009b) } \\
\text { Wan et al. (2009a) }\end{array}$ \\
\hline $1.6 \pm 0.5$ & $26 \pm 35$ & $9 \pm 10$ & 2.9 & Reno, NV & Peterson et al. (2009) \\
\hline $2.0 \pm 0.7$ & $18 \pm 22$ & $7 \pm 7$ & 2.6 & Reno, NV & Lyman and Gustin (2009) \\
\hline 1.59 & 6.8 & 1.52 & 4.5 & New Mexico & Caldwell et al. (2006) \\
\hline $1.3 \pm 0.4$ & $1.3 \pm 3.3$ & $4.1 \pm 7.8$ & 0.32 & Rochester, NY & Choi et al. (2012) \\
\hline $1.6 \pm 0.4$ & $5.6 \pm 10.3$ & $8.7 \pm 12.8$ & 0.64 & Huntington Forest, NY & Choi et al. (2012) \\
\hline $1.96 \pm 0.38$ & $2.53 \pm 4.09$ & $12.50 \pm 5.88$ & 0.20 & Gothenburg, Sweden & Li et al. (2008) \\
\hline 4.7 & 6.2 & 30.7 & 0.20 & Mt. Gongga, China & Fu et al. (2008) \\
\hline $1.5-2.0$ & $0-5$ & $0-30$ & $\sim 0.17$ & Yellowstone National Park & Hall et al. (2006) \\
\hline $1.62 \pm 0.32$ & $3.8 \pm 8.9$ & $8.6 \pm 8.3$ & 0.44 & Devil's Lake, WI & Manolopoulos et al. (2007) \\
\hline $2.2 \pm 1.3$ & $17.7 \pm 28.9$ & $20.8 \pm 30.0$ & 0.84 & Detroit, MI & Liu et al. (2007) \\
\hline 1.54 & 43 & 5.2 & 8.3 & Mt. Bachelor, OR & Swartzendruber et al. (2006) \\
\hline $4.05 \pm 1.28$ & $13.6 \pm 20.4$ & $16.4 \pm 19.5$ & 0.83 & Tuscaloosa, AL & Gabriel et al. (2005) \\
\hline $3.20 \pm 0.66$ & $13.6 \pm 7.4$ & $9.73 \pm 6.9$ & 1.40 & Cove Mountain, TN & Gabriel et al. (2005) \\
\hline $1.65 \pm 0.42$ & $3 \pm 11$ & $26 \pm 54$ & 0.12 & St. Anicet, QC & Poissant et al. (2005) \\
\hline 1.38 & 3.63 & 6.44 & 0.56 & St. Francois wetlands, QC & Poissant et al. (2004) \\
\hline 1.9 & 18 & 25 & 0.72 & Neuglobsow, Germany & Munthe et al. (2003) \\
\hline 1.6 & 26 & 23 & 1.1 & Zingst, Germany & Munthe et al. (2003) \\
\hline 1.5 & 14 & 4 & 3.5 & Rörvik, Sweden & Munthe et al. (2003) \\
\hline 1.4 & 10 & 5 & 2.0 & Aspvreten, Sweden & Munthe et al. (2003) \\
\hline 1.8 & 18 & 2 & 9.0 & Mace Head, Ireland & Munthe et al. (2003) \\
\hline $1.7 \pm 0.5$ & $21 \pm 22$ & $42 \pm 50$ & 0.5 & Still Pond, MD & Sheu et al. (2002) \\
\hline $4.4 \pm 2.7$ & $89 \pm 150$ & $74 \pm 197$ & 1.20 & Baltimore, MD & Sheu et al. (2002) \\
\hline
\end{tabular}


Table 2. Description of model runs and most important parameters that were used in this study. The "base" experiment corresponds to configuration used in L. Zhang et al. (2012).

\begin{tabular}{llll}
\hline Experiment & $\mathrm{Hg}^{0}: \mathrm{Hg}^{2+}: \mathrm{Hg}_{\mathrm{p}}$ & Oxidant & Remarks \\
\hline Base & $50: 40: 10$ & $\mathrm{O}_{3} ;$ std rate & Base run \\
NoEmit & $100: 0: 0$ & $\mathrm{O}_{3} ;$ std rate & No anthropogenic $\mathrm{Hg}^{2+}$ and $\mathrm{Hg}_{\mathrm{p}}$ emissions \\
NoChem & $50: 40: 10$ & & No mercury chemistry \\
Ex-ox1.5-CFPP & $90: 5: 5$ & $\mathrm{O}_{3} ; 1.5 \times$ rate & Emission adjustment for coal-fired power plants (CFPPs) only \\
Ex-ox1 & $90: 8: 2$ & $\mathrm{O}_{3} ;$ std rate & Emission adjustment for all anthropogenic emissions \\
Ex-ox2 & $90: 8: 2$ & $\mathrm{O}_{3} ; 2 \times$ rate & Emission adjustment for all anthropogenic emissions \\
Ex-ox2-HiHgp & $90: 8: 2$ & $\mathrm{O}_{3} ; 2 \times$ rate & $\mathrm{Hg}^{2+}: \mathrm{Hg}_{\mathrm{p}}$ ratio $0.5: 0.5=>0.25: 0.75$ \\
Ex-oxOH & $90: 8: 2$ & $-\mathrm{OH}$ & $\cdot \mathrm{OH}$ oxidation \\
\hline
\end{tabular}

Table 3. Measurement details and limits of detection for $\mathrm{Hg}^{2+}$ and $\mathrm{Hg}_{\mathrm{p}}$ (all CVAFS; Tekran 2537A/1130/1135) at selected stations used for comparison with model results in L. Zhang et al. (2012). Method performance data and parameters as cited. MDL: method detection limit.

\begin{tabular}{|c|c|c|c|}
\hline Identifier/Site & $\operatorname{MDL}\left(\mathrm{pg} \mathrm{m}^{-3}\right)$ & Reference & Remarks \\
\hline OH02/Athens & $<1\left(\mathrm{Hg}^{2+}\right.$ and $\left.\mathrm{Hg}_{\mathrm{p}}\right)$ & Yatavelli et al. (2006) & $\begin{array}{l}\text { AMNet site } \\
1 \mathrm{~h} \mathrm{Hg}^{2+} \text { and } \mathrm{Hg}_{\mathrm{p}} \text { sampling }\end{array}$ \\
\hline NJ05/Brigantine & 1.0 (Species not given $)$ & Aucott et al. (2009) & $\begin{array}{l}\text { AMNet site } \\
1 \mathrm{~h} \mathrm{Hg}^{2+} \text { and } \mathrm{Hg}_{\mathrm{p}} \text { sampling }\end{array}$ \\
\hline NJ30/Chester & 1.0 (Species not given) & Aucott et al. (2009) & $\begin{array}{l}\text { AMNet site } \\
1 \mathrm{~h} \mathrm{Hg}^{2+} \text { and } \mathrm{Hg}_{\mathrm{p}} \text { sampling }\end{array}$ \\
\hline NJ54/Elizabeth & 1.0 (Species not given) & Aucott et al. (2009) & $\begin{array}{l}\text { AMNet site } \\
1 \mathrm{~h} \mathrm{Hg}^{2+} \text { and } \mathrm{Hg}_{\mathrm{p}} \text { sampling }\end{array}$ \\
\hline $\begin{array}{l}\text { ON18/Experimental } \\
\text { Lakes Area }\end{array}$ & NA & $\begin{array}{l}\text { C. Eckley (personal } \\
\text { communication, 2011); } \\
\text { L. Zhang (personal } \\
\text { communication, 2011); }\end{array}$ & $\begin{array}{l}\text { Environment Canada site } \\
3 \mathrm{~h} \mathrm{Hg}^{2+} \text { and } \mathrm{Hg}_{\mathrm{p}} \text { sampling }\end{array}$ \\
\hline NY20/Huntington & $\begin{array}{l}0.46\left(\mathrm{Hg}^{2+}\right) \\
1.10\left(\mathrm{Hg}_{\mathrm{p}}\right)\end{array}$ & Huang et al. (2010) & $\begin{array}{l}\text { AMNet site } \\
2 \mathrm{~h} \mathrm{Hg}^{2+} \text { and } \mathrm{Hg}_{\mathrm{p}} \text { sampling } \\
\text { Assuming same set-up as Rochester }\end{array}$ \\
\hline NJ30/New Brunswick & 1.0 (Species not given $)$ & Aucott et al. (2009) & $\begin{array}{l}\text { AMNet site } \\
1 \mathrm{~h} \mathrm{Hg}^{2+} \text { and } \mathrm{Hg}_{\mathrm{p}} \text { sampling }\end{array}$ \\
\hline NY43/Rochester & $\begin{array}{l}0.46\left(\mathrm{Hg}^{2+}\right) \\
1.10\left(\mathrm{Hg}_{\mathrm{p}}\right)\end{array}$ & Huang et al. (2010) & $\begin{array}{l}\text { AMNet site } \\
2 \mathrm{~h} \mathrm{Hg}^{2+} \text { and } \mathrm{Hg}_{\mathrm{p}} \text { sampling }\end{array}$ \\
\hline PQ04/St-Anicet & 3.75 (Species not given) & Poissant et al. (2005) & $\begin{array}{l}\text { Environment Canada site } \\
1 \mathrm{~h} \mathrm{Hg}^{2+} \text { and } \mathrm{Hg}_{\mathrm{p}} \text { sampling }\end{array}$ \\
\hline $\begin{array}{l}\text { NH06/Thompson } \\
\text { Farm }\end{array}$ & $0.1\left(\mathrm{Hg}^{2+}\right)$ & Sigler et al. (2009) & $\begin{array}{l}\text { AMNet } \\
2 \mathrm{~h} \mathrm{Hg}^{2+} \text { sampling }\end{array}$ \\
\hline TORO/Toronto & $4\left(\mathrm{Hg}^{2+}\right.$ and $\left.\mathrm{Hg}_{\mathrm{p}}\right)$ & Song et al. (2009) & $\begin{array}{l}\text { Ryerson University } \\
1 \mathrm{~h} \mathrm{Hg}^{2+} \text { and } \mathrm{Hg}_{\mathrm{p}} \text { sampling }\end{array}$ \\
\hline Laboratory study & $\begin{array}{l}6.2 / 3.1\left(\mathrm{Hg}^{2+}\right) \\
1 \mathrm{~h} / 2 \mathrm{~h} \text { sampling }\end{array}$ & Landis et al. (2002) & Characterisation of denuder method \\
\hline
\end{tabular}

Tossell (2003), Shepler and Peterson (2003) and Goodsite et al. (2004) concluded that $\mathrm{Hg}^{0}+\mathrm{O}_{3}$ and $\mathrm{Hg}^{0}+\mathrm{OH}$ reactions should not be significant in the atmosphere since $\mathrm{HgOH}^{+}$, a possible intermediate of the reaction $\mathrm{Hg}^{0}+\mathrm{OH}$, is likely to dissociate based on the binding energy, and the production of $\mathrm{HgO}_{(\mathrm{g})}$, as a product of these reactions, is highly endothermic. However, in a more recent theoretical work, Cremer et al. (2008) found the reaction energy of $\mathrm{Hg}^{0}+\mathrm{OH}$ to be comparable to the reaction energy for $\mathrm{Hg}^{0}+\mathrm{Br}$, and concluded that the reaction $\mathrm{Hg}^{0}+\mathrm{OH}$ is possible in the atmosphere. Use of much larger reaction chamber and low reactant concentrations in more recent studies of $\mathrm{Hg}^{0}+\mathrm{O}_{3}$ reaction suggests that the rate constants obtained previously are viable in the atmosphere and are free of surface effects (Snider et al., 2008; Sumner et al., 2005). Tossell (2006) suggest that stable oligomers of $\mathrm{Hg}$ oxide, $\mathrm{HgO}_{n}$, can subsist in the atmosphere. In a more recent experimental study, Rutter et al. (2012) found the reaction $\mathrm{Hg}^{0}+\mathrm{O}_{3}$ to be viable in the presence of 
atmospheric aerosols and recommend the inclusion of this reaction in the models. Calvert and Lindberg (2005) and Subir et al. (2012) suggest that $\mathrm{Hg}^{0}$ oxidation by $\mathrm{O}_{3}$ and $\mathrm{OH}$ may be occurring in the atmosphere through complex reaction mechanism possibly involving surfaces. Subir et al. (2012) suggest that, given the abundance of $\mathrm{O}_{3}$ and $\mathrm{OH}$ radicals in the atmosphere, the $\mathrm{Hg}^{0}$ oxidation with $\mathrm{O}_{3}$ and $\mathrm{OH}$ should not be eliminated from $\mathrm{Hg}$ models.

$\mathrm{Hg}^{0}+\mathrm{Br}$ reaction is generally accepted as an important oxidation pathway in the atmosphere in the polar regions and marine boundary layer; however, very little data exists with respect to its mechanism in the global atmosphere (Dibble et al., 2012). Holmes (2012) investigated $\mathrm{Br}$ vs. $\mathrm{O}_{3} / \mathrm{OH}$ mechanisms as main oxidants of $\mathrm{Hg}^{0}$ in the atmospheric models based on observational constraints and concluded that both $\mathrm{Br}$ and $\mathrm{OH} / \mathrm{O}_{3}$ oxidation mechanisms are capable of reproducing the distribution of $\mathrm{Hg}$ at northern mid-latitudes; however some of the observed features of atmospheric $\mathrm{Hg}$ were better described by $\mathrm{O}_{3} / \mathrm{OH}$ oxidation mechanism while others were better described by $\mathrm{Br}$ oxidation mechanism. Holmes (2012) suggested that both oxidation mechanisms, and possibly others, may be present together in the atmosphere. Since $\mathrm{Hg}^{0}$ oxidation by $\mathrm{Br}$ is well demonstrated in the Marine Boundary Layer (MBL) and the polar regions, currently GRAHM uses this oxidation pathway only in these environments.

Only a limited number of reduction pathways for $\mathrm{Hg}$ in the aqueous phase have been identified. Recently, Si and Ariya (2008) studied reduction of $\mathrm{Hg}^{2+}$ by dicarboxylic acids $\left(\mathrm{C}_{2}-\mathrm{C}_{4}\right)$ in aqueous phase. Although they proposed a tentative reaction mechanism, sufficient details are unavailable for its implementation in the model. Moreover, they found that presence of chloride ion and dissolved oxygen significantly inhibited the reduction reaction; therefore this reduction pathway may not be significant in atmosphere. Hynes et al. (2009) concluded that the atmospheric importance of $\mathrm{Hg}$ reduction processes has not been established for any of the suggested reductants for $\mathrm{Hg}^{2+}$ so far; so the role of $\mathrm{Hg}^{2+}$ reduction in the global atmosphere remains conjectural. Determined reaction rate constants for the oxidation of $\mathrm{Hg}^{0}$ by $\mathrm{O}_{3}, \mathrm{OH}$ and $\mathrm{Br}$ in the atmosphere suggest significantly shorter lifetime of $\mathrm{Hg}^{0}$ in the atmosphere compared to the $\sim 1$ yr lifetime suggested by the observations. This implies that important unknown reduction processes are occurring in the atmosphere. Possible reduction of oxidized mercury on surfaces of atmospheric aerosols, ice and snow, etc. could be important but has not been studied so far.

\subsection{Sampling, measurement and data analysis of oxidized mercury species}

While several methods for the measurement of mercury species in the atmosphere have been developed (Munthe et al., 2001), the most popular methodology for fielddeployed systems and continuous monitoring is the detection of mercury species using cold vapour atomic fluorescence spectrometry (CVAFS) (Bloom and Fitzgerald, 1988). The widely employed Tekran 2537A analyzer system quantifies mercury species as $\mathrm{Hg}^{0}$ after amalgamation and concentration on a gold surface followed by thermal desorption into the CVAFS analysis system.

Mercury fractionation, commonly called "speciation", although the "species" definition for Tekran measurements is strictly operational, is achieved using two different inline sampling protocols, for $\mathrm{Hg}^{2+}$ and $\mathrm{Hg}_{\mathrm{p}}$ species. $\mathrm{KCl}$-coated annular denuders made of quartz are most commonly used for $\mathrm{Hg}^{2+}$ at air sample flow rates of $10 \mathrm{~L} \mathrm{~min}^{-1}$ leading to the collection of species on the modified denuder surface, followed by thermal desorption and detection. $\mathrm{Hg}_{\mathrm{p}}$ is deposited on a quartz filter surface followed by pyrolysis and detection (Lindberg et al., 2002). A combination set-up was commercialized by Tekran as systems $1130\left(\mathrm{Hg}^{2+}\right)$ and 1135 $\left(\mathrm{Hg}_{\mathrm{p}}\right)$ speciation units, which are now used for $\mathrm{Hg}$ concentration monitoring. Samples are sequentially desorbed from the collection device and analysed as $\mathrm{Hg}^{0}$ after reduction using CVAFS. Table 3 lists sampling times for $\mathrm{Hg}^{2+}$ and $\mathrm{Hg}_{\mathrm{p}}$, which are comparatively long (hours vs. typically $5 \mathrm{~min}$ for $\mathrm{Hg}^{0}$ ) due to the low concentrations observed (Landis et al., 2002). The table also illustrates the large variability of sampling times and resulting differences in the method detection limit (MDL), which is difficult to estimate due to lack of standards for $\mathrm{Hg}^{2+}$ and $\mathrm{Hg}_{\mathrm{p}}$. The MDL is certainly dependent on sampling time and the quantity of material collected for analysis and varies between 1.0 and $4.0 \mathrm{pg} \mathrm{m}^{-3}$. The MDL is not always specified separately for $\mathrm{Hg}^{2+}$ and $\mathrm{Hg}_{\mathrm{p}}$, and the mode of calculation is rarely reported. A better documented rationale for $\mathrm{Hg}^{2+}$ and $\mathrm{Hg}_{\mathrm{p}}$ MDLs is desirable since observed concentrations are often, if not mostly, below or around the MDL for both species and actively being addressed (Steffen et al., 2012).

Measurement data and the range for yearly means used for analysis in this study are listed in Table 4 and represent an expanded data set including but not limited to sites from Table 3 in order to allow for a comparison on a continental scale and maintain comparability with results from L. Zhang et al. (2012). Data from 21 sites were analysed with 2 colocated instruments for a total of 41 yearly data sets from 2002 to 2010. A minimum of 7 (seven) months of observations per year was required for a data set to qualify for consideration. Co-located data were treated as coming from a single location, i.e. for MS12 and NY43, respectively (also shown in Fig. 1).

Estimations from the model base run and modified runs were compared with observations by calculating the unbiased root mean square error (URMSE) and bias for yearly means and the correlation of weekly averaged data for time series analyses. Observation data were obtained from principal investigators and consisted of blank-corrected, but not MDL-censored concentrations from individual CVAFS runs. Missing data were marked as "not available" (NA) for 
Table 4. Observation sites for data used in this study. Two site identifiers at the same location indicate co-located instrument data. Yearly means $\left(\mathrm{pg} \mathrm{m}^{-3}\right)$ for multiple years are similar. Sites were classified as $\mathrm{C}=$ close $\left(60-90 \mathrm{pg} \mathrm{m}^{-3}\right)$, and $\mathrm{I}=$ intermediate proximity to sources $\left(30-60 \mathrm{pg} \mathrm{m}^{-3}\right)$ and $\mathrm{F}=$ far from sources $\left(0-30 \mathrm{pg} \mathrm{m}^{-3}\right)$ according to model calculation results plotted in Fig. 5. PI and data providers as of October 2010.

\begin{tabular}{|c|c|c|c|c|c|c|c|}
\hline Site ID & Location & Lat & Long & Obs Years & PI/Data Provider & Yearly average & Site \\
\hline $\mathrm{AB} 14$ & Genesee, $\mathrm{AB}$ & 53.3016 & -114.201 & 2009 & $\begin{array}{l}\text { Jacques Whitford } \\
\text { Axys Ltd. }\end{array}$ & $\begin{array}{l}\mathrm{Hg}^{2+}: 7.11 \\
\mathrm{Hg}_{\mathrm{p}}: 4.95\end{array}$ & $\mathrm{~F}$ \\
\hline ALER & Alert, NU & 82.5000 & -62.3330 & 2002-2009 & Steffen, EC & $\begin{array}{l}\mathrm{Hg}^{2+}: 7.69-30.8 \\
\mathrm{Hg}_{\mathrm{p}}: 4.95-47.2\end{array}$ & $\mathrm{~F}$ \\
\hline HALI & Halifax, NS & 44.6700 & -63.6100 & 2010 & Tordon, EC & $\begin{array}{l}\mathrm{Hg}^{2+}: 2.99 \\
\mathrm{Hg}_{\mathrm{p}}: 2.52\end{array}$ & $\mathrm{~F}$ \\
\hline MD08 & Piney Reservoir, MD & 39.7053 & -79.0122 & 2008-2009 & $\begin{array}{l}\text { Castro, MD State } \\
\text { University }\end{array}$ & $\begin{array}{l}\mathrm{Hg}^{2+}: 8.79-15.9 \\
\mathrm{Hg}_{\mathrm{p}}: 1.81-6.43\end{array}$ & I \\
\hline $\begin{array}{l}\text { MS12/ } \\
\text { MS99 }\end{array}$ & Grand Bay, MS & 30.4294 & -88.4277 & 2008-2009 & $\begin{array}{l}\text { Brooks/Luke, } \\
\text { NOAA }\end{array}$ & $\begin{array}{l}\mathrm{Hg}^{2+}: 7.52-9.94 \\
\mathrm{Hg}_{\mathrm{p}}: 4.33-5.39\end{array}$ & $\mathrm{~F}$ \\
\hline NH06 & Thompson Farm, NH & 43.1100 & -70.9500 & 2009 & University of $\mathrm{NH}$ & $\begin{array}{l}\mathrm{Hg}^{2+}: 3.35 \\
\mathrm{Hg}_{\mathrm{p}}: 2.46\end{array}$ & $\mathrm{~F}$ \\
\hline NJ30 & New Brunswick, NJ & 40.4728 & -74.4225 & $\begin{array}{l}2005 \text { and } \\
2009\end{array}$ & $\begin{array}{l}\text { Zsolway, NJ State } \\
\text { University }\end{array}$ & $\begin{array}{l}\mathrm{Hg}^{2+}: 3.82-8.23 \\
\mathrm{Hg}_{\mathrm{p}}: 7.04-14.8\end{array}$ & $\mathrm{C}$ \\
\hline NJ32 & Chester, NJ & 40.7876 & -74.6763 & $\begin{array}{l}2005 \text { and } \\
2009\end{array}$ & $\begin{array}{l}\text { Zsolway, NJ State } \\
\text { University }\end{array}$ & $\begin{array}{l}\mathrm{Hg}^{2+}: 6.38-10.2 \\
\mathrm{Hg}_{\mathrm{p}}: 10.5-12.1\end{array}$ & $\mathrm{C}$ \\
\hline NJ54 & Elizabeth, NJ & 40.6414 & -74.2084 & 2005 & $\begin{array}{l}\text { Zsolway, NJ State } \\
\text { University }\end{array}$ & $\begin{array}{l}\mathrm{Hg}^{2+}: 11.0 \\
\mathrm{Hg}_{\mathrm{p}}: 11.4\end{array}$ & $\mathrm{C}$ \\
\hline NS01 & Kejimkujik, NS & 44.4336 & -65.2060 & 2009 & Tordon/Steffen, EC & $\begin{array}{l}\mathrm{Hg}^{2+}: 0.474 \\
\mathrm{Hg}_{\mathrm{p}}: 5.72\end{array}$ & $\mathrm{~F}$ \\
\hline NY06 & Bronx, NY & 40.8680 & -73.8782 & 2009 & $\begin{array}{l}\text { Felton, NY State } \\
\text { University }\end{array}$ & $\begin{array}{l}\mathrm{Hg}^{2+}: 14.3 \\
\mathrm{Hg}_{\mathrm{p}}: 16.1\end{array}$ & $\mathrm{~F}$ \\
\hline NY20 & Huntington Forest, NY & 43.9731 & -74.2231 & 2008-2009 & $\begin{array}{l}\text { Holsen, Clarkson } \\
\text { University }\end{array}$ & $\begin{array}{l}\mathrm{Hg}^{2+}: 0.907-1.62 \\
\mathrm{Hg}_{\mathrm{p}}: 1.83-6.04\end{array}$ & $\mathrm{~F}$ \\
\hline $\begin{array}{l}\text { NY43/ } \\
\text { NY95 }\end{array}$ & Rochester, NY & 43.1544 & -77.6160 & 2008-2009 & $\begin{array}{l}\text { NY43: Holsen, } \\
\text { Clarkson } \\
\text { University } \\
\text { NY 95: Felton, } \\
\text { NY State } \\
\text { University }\end{array}$ & $\begin{array}{l}\mathrm{Hg}^{2+}: 7.40-10.0 \\
\mathrm{Hg}_{\mathrm{p}}: 10.0-16.1\end{array}$ & $\mathrm{~F}$ \\
\hline $\mathrm{OH} 02$ & Athens, $\mathrm{OH}$ & 39.3000 & -82.1167 & 2008-2009 & $\begin{array}{l}\text { Crist/Conley, Ohio } \\
\text { University }\end{array}$ & $\begin{array}{l}\mathrm{Hg}^{2+}: 12.1-16.2 \\
\mathrm{Hg}_{\mathrm{p}}: 7.82-9.57\end{array}$ & I \\
\hline OK99 & Stilwell, OK & 35.7514 & -94.6717 & 2009 & $\begin{array}{l}\text { Callison/Scrapper, } \\
\text { Cherokee Nation }\end{array}$ & $\begin{array}{l}\mathrm{Hg}^{2+}: 2.93 \\
\mathrm{Hg}_{\mathrm{p}}: 4.06\end{array}$ & $\mathrm{~F}$ \\
\hline ON18 & $\begin{array}{l}\text { Experimental Lakes } \\
\text { Area, ON }\end{array}$ & 49.6639 & -93.7211 & $\begin{array}{l}2005-2006 \\
\text { and } 2009\end{array}$ & Eckley, EC & $\begin{array}{l}\mathrm{Hg}^{2+}: 0.376-1.33 \\
\mathrm{Hg}_{\mathrm{p}}: 3.23-5.26\end{array}$ & $\mathrm{~F}$ \\
\hline PQ04 & St. Anicet, QC & 45.1167 & -74.2830 & $\begin{array}{l}2003,2005 \\
\text { and } 2009\end{array}$ & Poissant, EC & $\begin{array}{l}\mathrm{Hg}^{2+}: 3.21-4.99 \\
\mathrm{Hg}_{\mathrm{p}}: 12.8-25.8\end{array}$ & $\mathrm{~F}$ \\
\hline TORO & Toronto, ON & 43.6700 & -79.4000 & 2004 & $\begin{array}{l}\text { Lu, Ryerson } \\
\text { University }\end{array}$ & $\begin{array}{l}\mathrm{Hg}^{2+}: 14.5 \\
\mathrm{Hg}_{\mathrm{p}}: 22.1\end{array}$ & $\mathrm{~F}$ \\
\hline UT97 & Salt Lake City, UT & 40.7118 & -111.961 & 2009 & $\begin{array}{l}\text { Olson, Utah State } \\
\text { University }\end{array}$ & $\begin{array}{l}\mathrm{Hg}^{2+}: 23.5 \\
\mathrm{Hg}_{\mathrm{p}}: 15.5\end{array}$ & $\mathrm{C}$ \\
\hline VT99 & Underhill, VT & 44.5283 & -72.8689 & 2008 & $\begin{array}{l}\text { Miller, Ecosystems } \\
\text { Research }\end{array}$ & $\begin{array}{l}\mathrm{Hg}^{2+}: 4.12 \\
\mathrm{Hg}_{\mathrm{p}}: 13.4\end{array}$ & $\mathrm{~F}$ \\
\hline WOOD & Woods Hole, MA & 41.5267 & -70.6631 & 2008 & Engle, USGS & $\begin{array}{l}\mathrm{Hg}^{2+}: 2.03 \\
\mathrm{Hg}_{\mathrm{p}}: 2.91\end{array}$ & $\mathrm{~F}$ \\
\hline
\end{tabular}




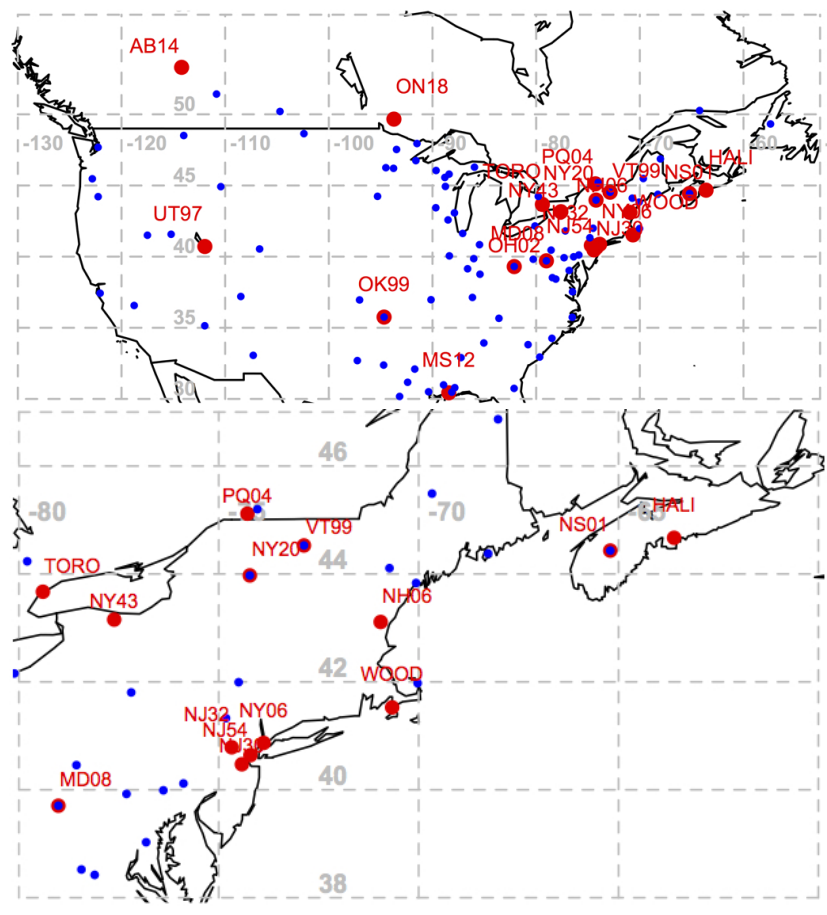

Fig. 1. (a) Location of measurement sites evaluated: oxidized mercury (red) and wet deposition (blue). (b) Zoomed insert shows northeastern sampling and evaluation sites resolved. Sampling station at Alert, NU, at the northern tip of Ellesmere Island not shown.

calculations; zero data as a result of blank correction were kept as is. Negative data as a result of blank correction were replaced by zero. Kaplan-Meier (KM) methods were employed for all calculations to avoid the introduction of a bias by arbitrarily assigning zero or $0.5 \mathrm{MDL}$ to data below the reporting limit (Helsel, 2005). KM daily, weekly and monthly means were compared to corresponding arithmetic means from model estimates (not shown). For sets with the vast majority of data points above the MDL ( $>90 \%$, e.g. for $\mathrm{Hg}^{0}$ ), no significant difference was observed between $\mathrm{KM}$ and normally averaged data. For $\mathrm{Hg}^{2+}$ and $\mathrm{Hg}_{\mathrm{p}}$ data, however, up to $80 \%$ was $<$ MDL resulting in differences for mean values of up to $16 \%$ comparing $\mathrm{KM}$ and normally averaged data sets. Statistical calculations and analyses were carried out employing R (version 2.14), a programming language for statistical computing and graphics.

\section{Results and discussion}

\subsection{Uncertainty of CVAFS measurements}

Atmospheric mercury measurement data from 15 sites around the Great Lakes region and the eastern United States were used by L. Zhang et al. (2012) for comparison with model estimates. These data and the additional data used in this study were collected as part of AMNet and Environ- ment Canada sampling and measurement stations and were in reasonable agreement regarding instrumentation and operating parameters (see Table 3 for remarks; $\mathrm{Hg}^{2+}$ and $\mathrm{Hg}_{\mathrm{p}}$ sampling times show some notable differences). Most importantly, all experiments were carried out using the same type of instrumentation, thus eliminating uncertainties arising from different measurement principles, including species measured. Nevertheless, the employed sample collection and analyte detection method leads to significant uncertainties associated with the data, which will be discussed with a focus on $\mathrm{Hg}^{2+}$ and $\mathrm{Hg}_{\mathrm{p}}$, where due to low observed concentrations near the MDL the impact is most significant (Sigler et al., 2009).

The immediate sampling environment including inlet position of CVAFS sampling devices has a pronounced influence on $\mathrm{Hg}^{2+}$ concentrations. Forested areas tend to scrub $\mathrm{Hg}^{2+}$ concentrations in its surroundings leading to underestimation, when applying these concentrations to estimate concentrations above the canopy. Hence, results might not be representative for regional and larger scale predictions and, therefore, less suited for comparison (E. Prestbo, personal communication, 2011). The change of $\mathrm{Hg}^{2+}$ concentrations with altitude has not yet been studied in detail, and the effect of the immediate sampling environment on the $\mathrm{Hg}^{2+}$ concentration gradient from above to below the canopy is unknown. There are some indications that concentrations are higher with increasing altitude, but a statistical analysis has not been performed for lack of data. Concentration differences for $\mathrm{Hg}^{2+}$ measured with refluxing mist chambers were a factor of 4 apart (Lindberg and Stratton, 1998). Because of these local sub-grid effects, it can be assumed that some observations do not correspond to surface layer concentrations estimated by models.

\subsection{1 $\mathrm{Hg}^{2+}$ sampled as $\mathrm{Hg}^{0}$}

$\mathrm{Hg}^{0}$ concentrations are often measured with a Tekran 2537A unit without the speciation units (e.g. EC CAMNet). Higher concentrations were observed for $\mathrm{Hg}^{0}$ data from stand-alone systems compared to combination systems with denuder and quartz filter set-ups. At Alert, $\mathrm{NU}, \mathrm{Hg}^{0}$ data are available from both systems and significant differences are observed. It is unclear if co-sampled $\mathrm{Hg}^{2+}$ is the reason, since precautions (e.g. long sample lines) are taken to avoid crosscontamination. For $\mathrm{Hg}^{0}$ differences were calculated to be $18 \%$ with a yearly average of $1.5 \mathrm{ng} \mathrm{m}^{-3}$ for the standalone instrument vs. $1.3 \mathrm{ng} \mathrm{m}^{-3}$ for the combination system in 2005. For now, CAMNet reports data from stand-alone instruments for $\mathrm{Hg}^{0}$ at Alert and supplements $\mathrm{Hg}^{2+}$ and $\mathrm{Hg}_{\mathrm{p}}$ data from a combination system.

Reports indicate that $\mathrm{Hg}^{2+}$ tends to be measured together with $\mathrm{Hg}^{0}$ for some inlet configurations and environmental conditions. $\mathrm{Hg}^{2+}$ species have the tendency to stick to surfaces as demonstrated for $\mathrm{HgCl}_{2}$, and it is, therefore, thought to be analysed with $\mathrm{Hg}^{0}$ species. As a result a mercury 
concentration will be closer to total gaseous mercury, the sum of $\mathrm{Hg}^{0}$ and $\mathrm{Hg}^{2+}$. While the combination systems eliminate this drawback by sampling $\mathrm{Hg}^{2+}$ and $\mathrm{Hg}_{\mathrm{p}}$ right after the inlet, care has to be taken when comparing data coming from different sources and systems to account for operational differences.

\subsection{2 $\mathrm{Hg}^{2+}$ sampling uncertainties}

Since the true composition of $\mathrm{Hg}^{2+}$ is unknown, a detailed assessment of quantitative sampling of $\mathrm{Hg}^{2+}$ is impossible (Selin, 2009). Major species that are assumed to be part of $\mathrm{Hg}^{2+}$ are $\mathrm{HgCl}_{2}, \mathrm{HgBr}_{2}$ and $\mathrm{HgO}$ (Munthe et al., 2001; Aspmo et al., 2005; Lyman et al., 2010), and $\mathrm{Hg}^{2+}$ is (operationally) defined as water-soluble oxidized mercury species (Landis et al., 2002) that can be reduced by stannous chloride in aqueous solutions without pretreatment (Munthe et al., 2001). Reactive gaseous mercury (RGM) is a commonly used alternative term for these species. Other candidate compounds suggested for the $\mathrm{Hg}^{2+}$ component pool are cross halogen species with chlorine, bromine and iodine atoms. Their contribution to the overall $\mathrm{Hg}^{2+}$ concentration is unknown, and no literature data exist.

$\mathrm{HgCl}_{2}$ is commonly employed as a surrogate standard for $\mathrm{Hg}^{2+}$ to evaluate method performance, since it is a thermodynamically favoured product of fossil fuel and waste combustion facilities (Landis et al., 2002, citing Klockow et al., 1990). The full composition of the $\mathrm{Hg}^{2+}$ fraction captured by the annular denuder set-up is not known (Lindberg et al., 2007; Landis et al., 2002); it has been reported that species with diffusion coefficients $>0.1 \mathrm{~cm}^{2} \mathrm{~s}^{-1}$ are typically measured (Poissant et al., 2005). No further quantitative data are available, making a quantitative error analysis not feasible.

Recently, the impact of the presence of ozone on $\mathrm{Hg}^{2+}$ sampling using the denuder technique was investigated (Lyman et al., 2010). Significant loss of oxidized mercury $\left(\mathrm{HgCl}_{2}, \mathrm{HgBr}_{2}\right)$ as elemental mercury was observed in laboratory experiments (39-55\% loss) and at a field site (3$37 \%)$. Precision of replicate denuder measurements was determined to be around $30 \%$. Additionally collection efficiency of denuders for $\mathrm{HgCl}_{2}$ decreased by $12-30 \%$ in the presence of ozone. Hence, any $\mathrm{Hg}^{2+}$ will subsequently be detected as $\mathrm{Hg}^{0}$ employing the combination set-up with the denuder sampling device placed upstream of the $\mathrm{Hg}^{0}$ detection unit. Further investigation of ozone and other potential interfering oxidizing species such as peroxides is recommended.

\subsection{3 $\mathrm{Hg}_{\mathrm{p}}$ sampling and aerosol size distribution}

For $\mathrm{Hg}_{\mathrm{p}}$ sampling a quartz filter with an upper size cut-off at $2.5 \mu \mathrm{m}$ is employed (Landis et al., 2002). This raises issues with both ultrafine (UFP) and large particle fractions of the total aerosol distribution. For particles $>2.5 \mu \mathrm{m}$, Keeler et al. (1995) showed bimodal distribution with a second maximum at $3.8 \mu \mathrm{m}$ for some samples indicating that a signif- icant portion of mercury species from larger aerosol fractions are potentially not collected and reported as $\mathrm{Hg}_{\mathrm{p}}$. The lower size cut-off is less clearly defined. Mercury adhering to UFP shows gas-like behaviour despite its particulate character thus potentially misclassifying $\mathrm{Hg}_{\mathrm{p}}$ as $\mathrm{Hg}^{0}$ and $\mathrm{Hg}^{2+}$. The distinct character of UFP and its clusters apart from classic aerosol has been recognized as has its potential for heterogeneous chemistry reactions due to the large surface area. Mercury has not been determined in UFP, and the degree of underestimation by current sampling methodologies is not known.

Furthermore, for $1 \mathrm{~h}$ sampling durations elevated temperatures in the filter assembly (typically $50^{\circ} \mathrm{C}$ to exclude moisture) have been shown to lead to identification of $\mathrm{Hg}_{\mathrm{p}}$ as $\mathrm{Hg}^{2+}$ (Rutter and Schauer, 2007a). Prolonged collection times of up to $12 \mathrm{~h}$ as they often occur to reach the filter loadings necessary for detection led to filter losses for $\mathrm{Hg}_{\mathrm{p}}$ (Malcolm and Keeler, 2007). Collection times for the discussed studies were typically lower (1-3 h; see Table 3$)$, thus minimising the risk for filter losses.

\subsubsection{Operational uncertainties}

While AMNet has made considerable progress towards harmonisation of instrument operation, earlier data were not necessarily acquired in a fully standardised fashion. Different operating parameters might compromise comparability of data. These issues are being dealt with by an AMNet standard operating procedure (Steffen et al., 2012).

Among the issues to be addressed is the 2-point calibration at 0 and $15 \mathrm{ng} \mathrm{sm}^{-3}$ that the Tekran system uses, and for low concentrations problems with linearity of the calibration curve were previously reported (Swartzendruber et al., 2009). Since low concentrations (in the $\mathrm{pg} \mathrm{m}^{-3}$ range) are typically observed for $\mathrm{Hg}^{2+}$ and $\mathrm{Hg}_{\mathrm{p}}$, a thorough assessment of linearity is especially important for these species. $\mathrm{Hg}^{0}$ measurement uncertainty was reported to be $12-20 \%$ $(2 \sigma)$, which has direct implications for $\mathrm{Hg}^{2+}$ and $\mathrm{Hg}_{\mathrm{p}}$, since these species are ultimately detected as $\mathrm{Hg}^{0}$ (Aspmo et al., 2005; Temme et al., 2007 and Brown et al., 2008).

A good assessment of the method detection limit (MDL) is imperative for the same reasons. Sampling for $\mathrm{Hg}^{2+}$ and $\mathrm{Hg}_{\mathrm{p}}$ typically takes $1-3 \mathrm{~h}$ followed by $1 \mathrm{~h}$ of desorption and analysis (sum equals "cycle time"). Landis et al. (2002) found MDLs of $6.2 \mathrm{pg} \mathrm{m}^{-3}$ and $3.1 \mathrm{pg} \mathrm{m}^{-3}$ for $\mathrm{Hg}^{2+}$ for sampling durations of $1 \mathrm{~h}$ and $2 \mathrm{~h}$ at $10 \mathrm{~L} \mathrm{~min}^{-1}$ sample flow rate.

For the reviewed literature in Table 2, reported MDLs were around $1 \mathrm{pg} \mathrm{m}^{-3}$ and considerably lower than Landis' study. In discussions with instrument operators, values between 2.0 and $5.0 \mathrm{pg} \mathrm{m}^{-3}$ were reported (Tate, personal communication, 2011; C. Eckley, personal communication, 2011). Due to a lack of suitable standards, MDL calculations are not straightforward, and 3 times the standard deviation of the blank is most often used but deemed problematic due to large fluctuations of the blank. Operator experience was cited as a 
better but not objective means for what data could be trusted (C. Eckley, personal communication, 2011). Separate MDLs for $\mathrm{Hg}_{\mathrm{p}}$ are rarely specified. Depending on the MDL used for statistical calculations, a significant fraction (up to 40-80\%) of $\mathrm{Hg}^{2+}$ and $\mathrm{Hg}_{\mathrm{p}}$ data fall below the MDL with implications for interpretation and statistical procedures used (Engle et al., 2010). The uncertainty in establishing a suitable MDL together with data near the MDL highlights the challenges that a reliable determination of $\mathrm{Hg}^{2+}$ and $\mathrm{Hg}_{\mathrm{p}}$ face.

The precision of the denuder method was determined by the collection of co-located samples $(n=63)$ to be $15.0 \pm 9.3 \%$ (Landis et al., 2002). Precision for automated 1130/1135 methods is, according to Poissant et al. (2005), unknown and usually not listed.

\subsection{Statistical treatment of observational data}

With a large number of observations and observed concentrations at the MDL, a suitable treatment of data has to be employed to account for non-detect data. In the current literature environmental data are either used as-is or undergo some form of treatment, e.g. substitution with a fraction of the MDL, typically one-half, for values < MDL (Helsel, 2005). A considerable loss of information is the consequence, together with the potential introduction of a biased estimate and as a result fabricated data. In conjunction with the MDL used as a criterion for censoring data, significant differences and reliability of results can occur. For example raw data from Poissant et al. (2005) at St-Anicet, QC, have a reported MDL of $3.75 \mathrm{pg} \mathrm{m}^{-3}$. Due to its more rural location, a much smaller number of data points is $>$ MDL (22.2\%). Median and mean values are different for Kaplan-Meier treated data censoring at the MDL compared to classical statistics calculating the arithmetic mean and median: the median changes from 1.3 with classical treatment to $0.82 \mathrm{pg} \mathrm{m}^{-3}$ for KaplanMeier treated data. The change of the mean is smaller from 3.3 to $3.2 \mathrm{pg} \mathrm{m}^{-3}$. Concluding, a standardised procedure of data treatment has to be agreed upon that treats non-detects in a suitable fashion and takes into account instrument-specific MDLs. Methods such as robust statistics, Kaplan-Meier estimates and maximum likelihood estimation (MLE) are much more suitable for the treatment of censored environmental data (Helsel, 1990), especially for $\mathrm{Hg}^{2+}$ and $\mathrm{Hg}_{\mathrm{p}}$ concentrations, which are often found to be below the detection limit (Engle et al., 2010). Table 5 describes uncertainties for CVAFS measurements together with other sources of uncertainty related to emissions and atmospheric chemistry processes. Regarding measurements, individual parameter assessments (e.g. for accuracy and precision of the denuder sampler) are typically not available because of a lack of standards (Aspmo et al., 2005), but some estimates exist regarding the cumulative uncertainty of $\mathrm{Hg}^{2+}$ and $\mathrm{Hg}_{\mathrm{p}}$ measurements.

\subsection{Emission uncertainties}

Current emission inventories prescribe a fixed $\mathrm{Hg}^{0}: \mathrm{Hg}^{2+}: \mathrm{Hg}_{\mathrm{p}}$ emission ratio for any coal-fired power plant (CFPP), currently 50\%:40\%:10\% (Pacyna et al., 2010). Stack data, however, indicate a large variability of the mercury species ratios between CFPPs, depending on multiple parameters such as air pollution control devices (APCD) used and the mercury content of coal burned at a given time (Hsi et al., 2010). Such variations are not accounted for in inventories.

Measurements of mercury species at observation sites near CFPPs revealed that there was indeed a large variability in, for example, $\mathrm{Hg}^{2+}$ emissions ranging from 5 to $35 \%$ during different plume events at a sampling site with three $\mathrm{CF}$ PPs within a $<60$ mile radius and 4 to $29 \%$ for a sampling site with a single CFPP within 15 miles (Edgerton et al., 2006). Quite variable data on mercury species' contributions to flue gas composition were also recently published for South Korea showing differences between bituminous coal $\left(\mathrm{Hg}^{2+}: 0.73 \mu \mathrm{g} \mathrm{m}^{-3}\right.$ after treatment) and anthracite $\left(\mathrm{Hg}^{2+}\right.$ : $1.41 \mathrm{~g} \mathrm{~m}^{-3}$ ) for CFPPs and treatment of flue gas using wet or dry APCD. Dry APCDs were reported to lead to higher $\mathrm{Hg}^{2+}$ concentrations, whereas wet treatment yielded less oxidized effluent gas (Kim et al., 2010). Incinerating facilities with $\mathrm{Hg}^{2+}$ concentrations in the flue gas after treatment were up to $190 \mu \mathrm{g} \mathrm{m}^{-3}$ for industrial waste incinerators. Wang et al. (2010) also reported significant variability of $\mathrm{Hg}^{2+}$ concentrations from different CFPP after flue gas treatment $(0.13$ to $24 \mu \mathrm{g} \mathrm{m}^{-3}$ ). Analysis of coal composition is also provided including correlation of $\mathrm{Hg}^{2+}$ with halogen content of the coal confirming previous studies that reported increased conversion to $\mathrm{Hg}^{2+}$ at high halogen content (e.g. Niksa et al., 2009). A summary of $\mathrm{Hg}^{2+}$ concentrations ranging from $2-76 \%$ in coal with 37 to $510 \mu \mathrm{g} \mathrm{kg}^{-1}$ total $\mathrm{Hg}$ including work by the authors also provides information on coal used and APCDs in place (Shah et al., 2010). Additionally modelled emission estimations for Chinese provinces by $\mathrm{Y}$. Wu et al. (2010) indicated a high uncertainty for $\mathrm{Hg}^{2+}$ of up to a factor of 3 .

\subsection{Uncertainties associated with chemistry knowledge gap}

CFPPs are considered the major source of anthropogenic mercury emissions due to the natural occurrence of mercury in coal at trace levels (Wang et al., 2010). Emitted mercury then undergoes reactions with a multitude of chemical species (Shah et al., 2010). Edgerton et al. (2006) and Weiss-Penzias et al. (2011) found that, at ground-based sites $7-15 \mathrm{~km}$ downwind of CFPPs, the fraction of oxidized mercury in total mercury concentrations was lower by a factor of $\sim 3-5$ than the fraction of oxidized mercury measured in CFPP stacks. In-plume reduction and/or uncertainties in measurement and emissions were suggested as possible 
Table 5. Quantitative uncertainty data for sampling, measurement (Tekran 2537A/1130/1135), emission and atmospheric chemistry-related parameters. Data are presented as calculated by the original authors. Summary discussed in Sect. 3.5.

\begin{tabular}{|c|c|c|c|c|}
\hline \# & Species & Process & Uncertainty & Reference \\
\hline 1 & $\mathrm{Hg}^{2+}$ & Replicate (manual) denuder measurements & $5.7-24 \%$ & Landis et al. (2002) \\
\hline 2 & $\mathrm{Hg}^{2+}$ & $\begin{array}{l}\text { Gain: Sample inlet position at ground and on flux } \\
\text { tower at } 43 \mathrm{~m} \text {; } 92 \text { samples measured }\end{array}$ & $400 \%$ & Lindbergh et al. (1998) \\
\hline 3 & $\mathrm{Hg}^{0}$ & Co-located instruments & $23 \%$ & \\
\hline 4 & $\mathrm{Hg}^{2+}$ & Co-located measurements & $30-40 \%$ & Author collective (2009) \\
\hline 5 & $\mathrm{Hg}^{2+}$ and $\mathrm{Hg}_{\mathrm{p}}$ & $\begin{array}{l}\text { Co-located measurements, manifold intercomparison } \\
\text { study; } 3 \text { systems }\end{array}$ & $\begin{array}{l}\mathrm{Hg}^{2+}: 10.2 \% \\
\mathrm{Hg}_{\mathrm{p}}: 31-54 \%\end{array}$ & Lyman and Gustin (2009) \\
\hline 6 & $\mathrm{Hg}^{2+}$ and $\mathrm{Hg}_{\mathrm{p}}$ & Loss: Incorrect baseline and integration & $20 \%$ & Swartzendruber et al. (2009) \\
\hline 7 & $\mathrm{Hg}^{2+}$ & Loss: $\mathrm{HgCl}_{2}$ collection efficiency with $50 \mathrm{pbb}$ ozone & $12-30 \%$ & Lyman et al. (2010) \\
\hline 8 & $\mathrm{Hg}^{2+}$ & $\begin{array}{l}\text { Loss: } \mathrm{HgCl}_{2} \text { after } 30 \text { min ozonation at } 30 \mathrm{pbb} \text { after } \\
\text { collection }\end{array}$ & $40-51 \%$ & Lyman et al. (2010) \\
\hline 9 & $\mathrm{Hg}^{2+}$ and $\mathrm{Hg}_{\mathrm{p}}$ & Estimated total measurement uncertainty & $\begin{array}{l}\mathrm{Hg}^{2+}: 26 \% \\
\mathrm{Hg}_{\mathrm{p}}: 33 \%\end{array}$ & Edgerton et al. (2006) \\
\hline 10 & $\mathrm{Hg}^{0}$ & Estimated total measurement uncertainty & $12 \%$ & Jaffe et al. (2005) \\
\hline 11 & $\mathrm{Hg}^{0}, \mathrm{Hg}^{2+}$ and $\mathrm{Hg}_{\mathrm{p}}$ & Emission uncertainty of individual power plants & $20-40 \%$ & Edgerton et al. (2006) \\
\hline 12 & $\mathrm{Hg}^{0}, \mathrm{Hg}^{2+}$ and $\mathrm{Hg}_{\mathrm{p}}$ & Emission uncertainty by source category & $<30 \%$ & Lindberg et al. (1998) \\
\hline 13 & $\mathrm{Hg}^{0}, \mathrm{Hg}^{2+}$ and $\mathrm{Hg}_{\mathrm{p}}$ & Air pollution control device used & NA & C. L. Wu et al. (2010) \\
\hline 14 & $\mathrm{Hg}^{2+}$ & Mercury content of coal burned & $100 \%$ & Kim et al. (2010) \\
\hline 15 & $\mathrm{Hg}^{2+}$ & Modelled reduction after adsorption & $23 \%$ & Vijayaraghavan et al. (2008) \\
\hline
\end{tabular}

causes. In an in-plume measurement study, ter Schure et al. (2011) concluded that significant reduction of $\mathrm{Hg}^{2+}$ occurs in CFPP plumes. Observations from a CFPP at Nanticoke, ON, showed a discrepancy between stack and inplume $\mathrm{Hg}^{2+}$ concentrations; the $\mathrm{Hg}^{0}: \mathrm{Hg}^{2+}: \mathrm{Hg}_{\mathrm{p}}$ ratios were reduced to an approximate ratio of $82 \%: 13 \%: 5 \%$ in the plume compared to $53 \%: 43 \%: 4 \%$ at the stack (Deeds et al., 2013). However, because of the differences between the two measurement techniques used in-stack and on the aircraft, the authors were unable to attribute the discrepancy between the in-stack and in-plume $\mathrm{Hg}$ speciation to the inplume reduction of $\mathrm{Hg}^{2+}$ to $\mathrm{Hg}^{0}$, but rather suggest that $\mathrm{Hg}^{0}$ concentration changes are due to plume dilution after leaving the stack.

In contrast to the above studies, concurrently measured concentrations of $\mathrm{Hg}^{2+}$ and $\mathrm{SO}_{2}$ suggest potential oxidation of $\mathrm{Hg}^{0}$ at the Devil's Lake site in rural Wisconsin (Manolopoulos et al., 2007). Also increase of $\mathrm{Hg}^{2+}$ concentrations with increasing distance of the plume from the source was also presented (Kolker et al., 2010). A lack of understanding of atmospheric mercury chemistry was underlined by recent measurements of elevated concentrations of $\mathrm{Hg}^{2+}$ in anthropogenic pollution plumes pointing to oxidation of $\mathrm{Hg}^{0}$ (Timonen et al., 2012). Vijayaraghavan et al. (2008) incorporated a rapid in-plume reduction of $\mathrm{Hg}^{0}$ by $\mathrm{SO}_{2}$ in a regional model study and found that this improved the wet deposition estimates in the Northeast US. Considering limited and contrasting observational evidence, the mechanism of in-plume chemistry is unclear.
There is also evidence for $\mathrm{Hg}^{2+}$ adsorption on particles (Rutter and Schauer, 2007a) and an adsorption mechanism was introduced into initial model calculations resulting in a ground-level $\mathrm{Hg}^{2+}$ reduction by $23 \%$ (Vijayaraghavan et al., 2008). Temperature-dependent adsorption ratios were also investigated in model calculations, resulting in a $90 \%$ reduction of $\mathrm{Hg}^{2+}$ concentrations in cold air (Rutter and Schauer, 2007a, b), modelled in GEOS-Chem (Amos et al., 2012). Both mechanisms, in-plume reduction by $\mathrm{SO}_{2}$ or other species and particle adsorption, could reduce $\mathrm{Hg}^{2+}$ estimates in the model, provided that evidence from observations supports these mechanisms, which so far is not the case for in-plume reduction processes. Lohman et al. (2006) and Vijayaraghavan et al. (2008) proposed a reduction mechanism for $\mathrm{Hg}^{2+}$ to $\mathrm{Hg}^{0}$ in the presence of $\mathrm{SO}_{2}$. Additional work, including stack and in-plume measurements, is necessary to reduce the high uncertainty associated with the proposed processes.

Limited reduction reactions in aqueous phase have been studied so far, and their atmospheric relevance has not been established (Hynes et al., 2009). Given that determined reaction rates suggest significantly shorter lifetime of $\mathrm{Hg}^{0}$ against oxidation by $\mathrm{O}_{3}, \mathrm{OH}$ and $\mathrm{Br}$ compared to the $\sim$ one year lifetime suggested by observations of $\mathrm{Hg}^{0}$ distribution in the atmosphere, there may be significant reduction processes occurring in the atmosphere which are currently unknown. Reduction of oxidized mercury on surfaces of atmospheric aerosols, ice and snow, etc. could be important but has not been studied so far. 
Recently, Y. Zhang et al. (2012) evaluated a nested-grid regional version of the GEOS-Chem model with AMNet data and found that assumption of in-plume reduction near the stack improves the model results. The significance of plume chemistry and atmospheric reduction processes (e.g. gas phase reactions, heterogeneous chemistry and aqueous chemistry) need to be further investigated as they could have a significant impact on $\mathrm{Hg}^{2+}$ and $\mathrm{H}_{\mathrm{p}}$ concentrations. A summary of uncertainties in atmospheric mercury chemistry was recently presented by Subir et al. (2011 and 2012).

\subsection{Summary of uncertainties}

The overall uncertainty and ultimately the discrepancy between measured and model concentrations arise from measurement errors of atmospheric concentrations and stack measurements. Furthermore, the accuracy and precision of model estimates is impacted by errors in emissions concentrations and lacking representation of chemical processes, one of which has been hypothesized to consist of in-plume reduction, albeit without confirmation from observations. Quantitative estimates of published uncertainties in measurements are summarized in Table 5. A quantitative summary estimate is difficult to achieve since the modes of calculation vary by author. A number of items lead to underestimation of measurement data, which could help in closing the gap between potentially overestimated model data and underestimated observations. Among these are the following for $\mathrm{Hg}^{2+}$ in Table 5: issues 6-8 result in losses and underestimation of oxidized mercury concentrations. Issue 2 could potentially lead to higher observed concentrations, reducing immediate local effects (Sect. 3.1). However, there is a significant lack of data requiring additional studies, and the item is excluded from subsequent calculations.

The summed-up average measurement uncertainties that lower concentrations (Table 5, items 6-8) are $86 \%$ for $\mathrm{Hg}^{2+}$. Calculating the root sum of squares of uncertainties for criteria that lower or increase concentrations results in $36 \%$ for $\mathrm{Hg}^{2+}$ (items 1, 4), $43 \%$ for $\mathrm{Hg}_{\mathrm{p}}$ (item 5), and $23 \%$ for $\mathrm{Hg}^{0}$ (item 3). The root sum of squares for anthropogenic emission uncertainties is $36 \%$ for $\mathrm{Hg}^{0}$ and $\mathrm{Hg}_{\mathrm{p}}$ (items 11,12 ) and $106 \%$ for $\mathrm{Hg}^{2+}$ (items 11, 12, 14). For item 12, $20 \%$ uncertainty was assumed for the emission uncertainty by source category (listed as $<30 \%$ ). These emission uncertainty estimates are in good agreement with the recently published Arctic Monitoring and Assessment Programme report, which lists anthropogenic $\mathrm{Hg}^{0}$ emission uncertainties at $20-40 \%$ (AMAP, 2011).

Additional sources of error not included in the above estimate stem from the differences between the sampling height and the model layer height used to extract the data. Also, the effects of vegetation on sampling carried out under the canopy may not be represented in the models (see Lindberg et al., 1998, for an example).
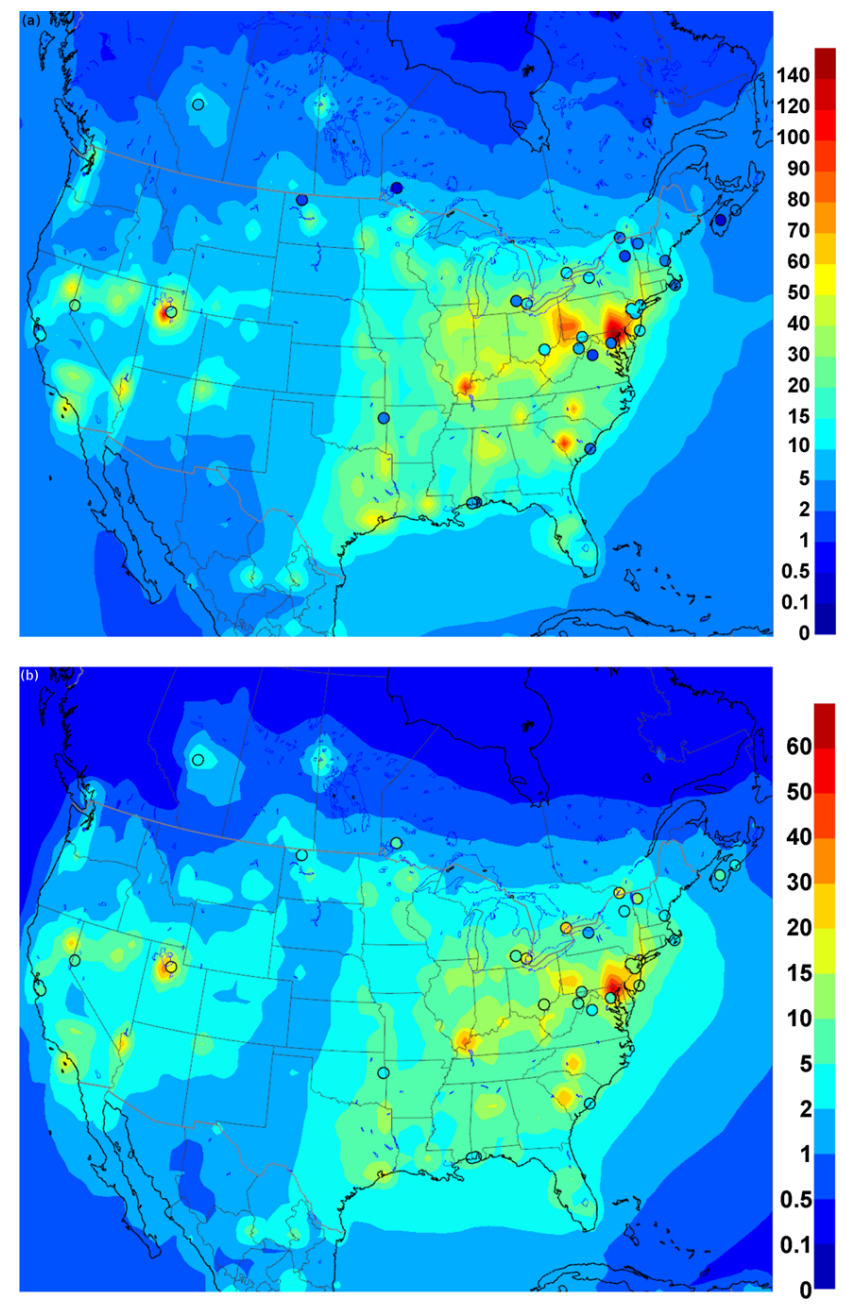

Fig. 2. Comparison of modelled and observed (circles) concentrations for (a) $\mathrm{Hg}^{2+}\left(\mathrm{pg} \mathrm{m}^{-3}\right)$ and (b) $\mathrm{Hg}_{\mathrm{p}}\left(\mathrm{pg} \mathrm{m}^{-3}\right)$ considering emissions only (NoChem; see Table 2 for details). A considerable discrepancy is observed especially in regions of high concentrations.

Table 5 demonstrates clearly that eliminating the discussed discrepancies and reducing observational uncertainties requires additional efforts from both modelling and measurement communities. The presented analysis, however, provides starting points to address the improvement of analytical and emission data: (1) choice of sampling locations and heights well represent atmospheric $\mathrm{Hg}^{2+}$ concentrations and are in-line with model vertical structure, (2) assessment of interferences such as ozone, (3) elimination of data analysis issues related to low $\mathrm{Hg}^{2+}$ and $\mathrm{Hg}_{\mathrm{p}}$ concentrations, and (4) improved treatment of CFPP emission estimates with regard to coal burned and flue gas treatment systems.

\subsection{Model sensitivity analysis}

The purpose of model sensitivity analysis in this study is to examine the discrepancy between measured and modelled 
oxidized mercury concentrations in light of other measurement constraints such as $\mathrm{Hg}^{0}$ concentrations and wet deposition which are known to be more reliable measurements compared to the oxidized mercury measurements. The base model simulation for 2005 was performed using the GRAHM configuration used in L. Zhang et al. (2012); ozone is the main oxidant in this simulation. Several model sensitivity runs were conducted to expose the knowledge gaps in $\mathrm{Hg}$ chemistry and uncertainties in measurements of $\mathrm{Hg}$ speciation in air and in emissions (Table 2 lists the experiments).

First experiment was conducted to examine the impact of anthropogenic emissions of $\mathrm{Hg}^{2+}$ and $\mathrm{Hg}_{\mathrm{p}}$ on the ambient concentrations of these species in the model by eliminating the mercury chemistry in the model (Experiment NoChem). The air concentrations of oxidized mercury in this model experiment are the result of atmospheric transport of these species from the anthropogenic sources and removal by dry and wet deposition processes. Figure 2 illustrates the comparison between model estimated surface air concentrations of $\mathrm{Hg}^{2+}$ and $\mathrm{Hg}_{\mathrm{p}}$ from "no chemistry" simulation and observed oxidized Hg concentrations. Even without the production of oxidized mercury through chemistry, an overprediction of up to 20 times for $\mathrm{Hg}^{2+}$ (for site NJ30 in 2009; see Table 4 for a detailed site description) and up to 7.6 times for $\mathrm{Hg}_{\mathrm{p}}$ (site MD08 in 2009) was found. The overprediction of oxidized mercury is seen to be largest in the vicinity of emission sources. The wet deposition (not shown here) is also overpredicted in the vicinity of emissions sources; however it is underpredicted away from the sources due to lack of oxidation processes. Since only anthropogenic emissions contribute to the emissions of oxidized mercury, significant overprediction of surface air concentrations of $\mathrm{Hg}^{2+}$ and $\mathrm{Hg}_{\mathrm{p}}$ and wet deposition in the vicinity of major emission sources suggests that either the speciation of $\mathrm{Hg}$ in the anthropogenic emissions is inaccurate or there are in-plume or other gas phase (and/or surface initiated) reduction reactions occurring in the atmosphere, which are very significant close to emission sources. The aqueous phase reduction processes in clouds cannot account for meaningful changes in speciation in the boundary layer as these processes are mostly active in free troposphere, and the cloud condensation occurs only $\sim 50 \%$ of the time in the atmosphere.

As seen in Fig. 2, the emission ratios of $\mathrm{Hg}^{0}: \mathrm{Hg}^{2+}: \mathrm{Hg}_{\mathrm{p}}$ at the stack and/or subsequent reactions in the plume appear to be important parameters and processes that need improvements to better represent atmospheric oxidized and particulate mercury concentrations in the models. In the absence of better knowledge of emission speciation and in-plume chemistry, several model sensitivity runs were conducted by changing the emission ratios of emitted $\mathrm{Hg}$ species at the sources to simulate the impact of reduced oxidized mercury emissions and/or in-plume reduction or possibly other gas/heterogeneous phase reduction processes near emission sources. Further sensitivity simulations were performed where anthropogenic emissions of oxidized mercury
$\left(\mathrm{Hg}^{2+}\right.$ and $\left.\mathrm{Hg}_{\mathrm{p}}\right)$ were completely eliminated from all sources (NoEmit); anthropogenic emissions of oxidized mercury were reduced for emissions from coal-fired power plants only $\left(\mathrm{Hg}^{0}: \mathrm{Hg}^{2+}: \mathrm{Hg}_{\mathrm{p}}\right.$ from $50: 40: 10$ to $90: 5: 5$; Ex-ox 1.5CFPP); anthropogenic emissions of oxidized mercury were reduced from all anthropogenic emissions $\left(\mathrm{Hg}^{0}: \mathrm{Hg}^{2+}: \mathrm{Hg}_{\mathrm{p}}\right.$ from $50: 40: 10$ to $90: 8: 2$; EX-ox1, Ex-ox2, Ex-ox2$\mathrm{HiHg}_{\mathrm{p}}$ and Ex-oxOH). The ratios for $\mathrm{Hg}^{0}: \mathrm{Hg}^{2+}: \mathrm{Hg}_{\mathrm{p}}$ were changed from $50: 40: 10$, in the base emissions inventory, to $90: 5: 5$ for coal-fired power plants in experiment Exox1.5-CFPP following the observations of these species in emission plume from a coal-fired plant in Ontario, Canada (Deeds et al., 2013). The ratios for $\mathrm{Hg}^{0}: \mathrm{Hg}^{2+}: \mathrm{Hg}_{\mathrm{p}}$ were changed from $50: 40: 10$, in the base emissions inventory, to $90: 8: 2$ for all anthropogenic emissions in experiments EX-ox1, Ex-ox2, Ex-ox2-HiHg and Ex-oxOH. The air concentrations of $\mathrm{Hg}^{2+}$ (gas) and $\mathrm{Hg}_{\mathrm{p}}$ are likely in equilibrium with each other; therefore, emissions of both $\mathrm{Hg}^{2+}$ and $\mathrm{Hg}_{\mathrm{p}}$ were reduced by the same factor keeping the ratio the same as the original inventory. Sensitivity experiment was also conducted where anthropogenic emissions of $\mathrm{Hg}^{2+}$ (gas) only were reduced. This experiment resulted in significant overprediction of $\mathrm{Hg}_{\mathrm{p}}$ and wet deposition near emission sources. The sensitivity experiments with reduced oxidized mercury emissions (for CFPP or all anthropogenic emissions) were first conducted using $\mathrm{Hg}^{0}+\mathrm{O}_{3}$ reaction rate coefficient as in the base case simulation (Hall, 1995). These simulations resulted in high bias in $\mathrm{Hg}^{0}$ background concentrations and low bias in wet deposition fluxes. Next, experiments were performed by incrementally increasing $\mathrm{Hg}^{0}+\mathrm{O}_{3}$ reaction rates until the background $\mathrm{Hg}^{0}$ concentrations were comparable to the measured $\mathrm{Hg}^{0}$ concentrations. The $\mathrm{O}_{3}$ reaction rate coefficient determined by Hall (1995) is an order of magnitude lower compared to the more recent rates determined for this reaction; therefore increase of ozone reaction rate by a factor of 1.5 or 2 is within the range of uncertainties in the determined rate constant for this reaction. An additional sensitivity experiment was performed using $\mathrm{OH}$ (no ozone oxidation) as the main oxidant of $\mathrm{Hg}^{0}$ in the atmosphere to investigate the impact of $\mathrm{OH}$ oxidation chemistry (along with modified $\mathrm{Hg}$ emission speciation) on the distribution of atmospheric $\mathrm{Hg}$ species in air and precipitation. Final experiment was performed by changing the ratio of gas phase oxidation products as $\mathrm{Hg}^{2+}$ and $\mathrm{Hg}_{\mathrm{p}}$ from $0.5: 0.5$ (base case) to $0.25: 0.75$.

The results of model sensitivity experiments that produced global background $\mathrm{Hg}^{0}$ concentrations compatible with the observations (along with "no chemistry" and "no oxidized mercury emissions" experiments) are discussed here. Figure 3 presents surface air mean, median and variance of yearly averaged $\mathrm{Hg}^{0}, \mathrm{Hg}^{2+}$ and $\mathrm{Hg}_{\mathrm{p}}$ concentrations and wet deposition fluxes of all sites in Table 4 estimated by base simulation, experiments and the measurements. Figure 4 shows the yearly bias for the different model runs listed in Table 2 . 

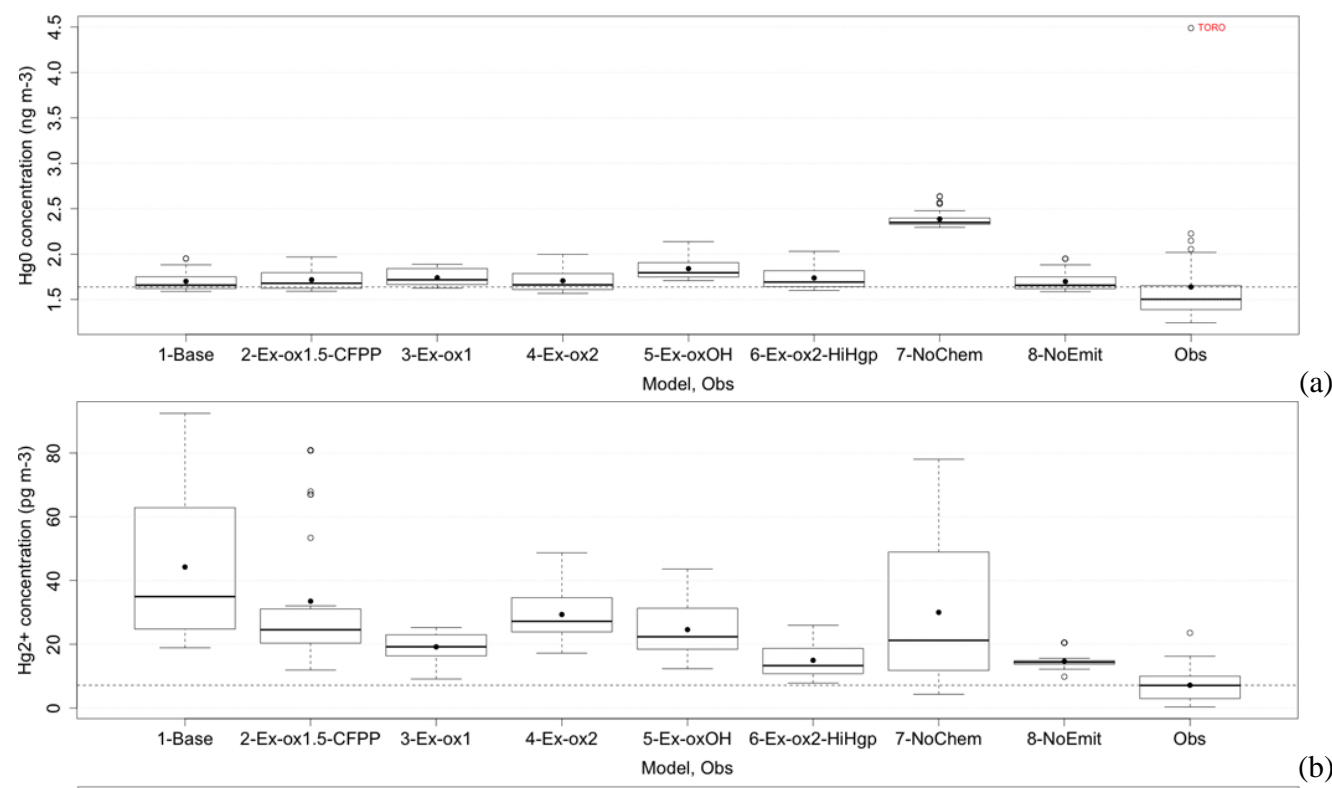

(b)
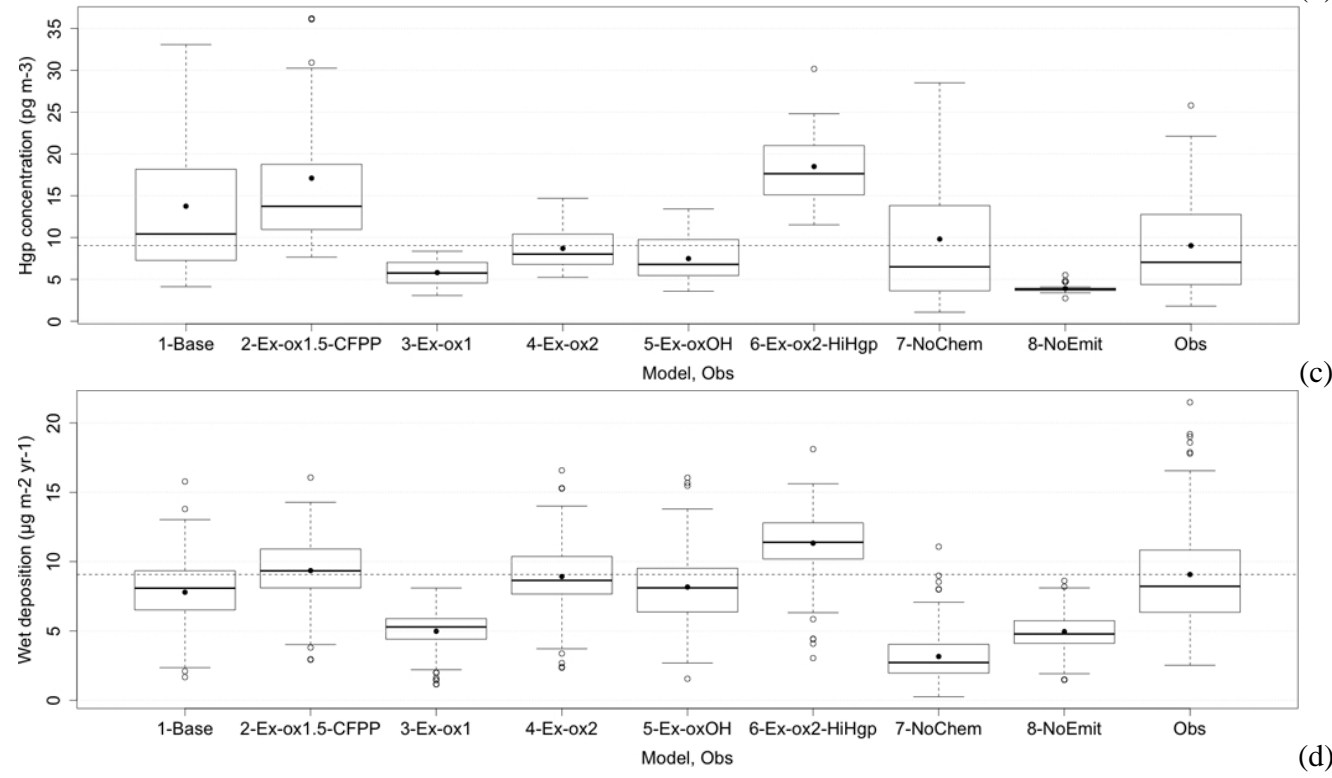

Fig. 3. Spread of yearly means for different model runs and observations. For a detailed model run description, see $\mathrm{Table}^{2}$. (a) $\mathrm{Hg}^{0}$, (b) $\mathrm{Hg}^{2+}$, (c) $\mathrm{Hg}_{\mathrm{p}}$, (d) wet deposition.

Average modelled median for $\mathrm{Hg}^{0}$ is slightly higher (by $7 \%$ ) in the Ex-oxOH run compared to the base run (by $0.13 \mathrm{ng} \mathrm{m}^{-3}$ with an estimated Ex-oxOH median value of $1.8 \mathrm{ng} \mathrm{m}^{-3}$ ), whereas variation in the Ex-oxOH compared to the base run is somewhat larger ( $10 \%$ vs. $3.5 \%$ of the mean), which is related to the representativeness of the resolution of the model. The $\mathrm{Hg}^{0}$ concentrations are seen to be invariant between experiments; however absence of $\mathrm{Hg}^{0}$ oxidation processes in the atmosphere leads to unrealistically high values of $\mathrm{Hg}^{0}$. Observed averaged mean $\mathrm{Hg}_{\mathrm{p}}$ concentration is slightly higher compared to the averaged median $\mathrm{Hg}^{2+}$ concentration; however observed averaged median $\mathrm{Hg}_{\mathrm{p}}$ concentration is lower compared to averaged mean $\mathrm{Hg}^{2+}$ concen- tration. Also, observed $\mathrm{Hg}^{2+}$ concentrations are more uniform within the domain (low variation) compared to the variability in $\mathrm{Hg}_{\mathrm{p}}$ concentrations. The experiment with no production of $\mathrm{Hg}^{2+}$ through atmospheric chemistry (NoChem experiment) results in significantly higher spatial variation and yearly mean concentrations of $\mathrm{Hg}^{2+}\left(30 \mathrm{pg} \mathrm{m}^{-3}\right)$ compared to observed $\left(7.2 \mathrm{pg} \mathrm{m}^{-3}\right)$. $\mathrm{Hg}_{\mathrm{p}}$ mean and median concentrations are only slightly elevated compared to measured values, whereas the variance between sites is higher compared to measurements. When no emission of $\mathrm{Hg}^{2+}$ is considered (NoEmit experiment), the chemistry alone produces lower concentrations of $\mathrm{Hg}_{\mathrm{p}}$; however, $\mathrm{Hg}^{2+}$ concentrations are still overestimated compared to observation. Chemically 

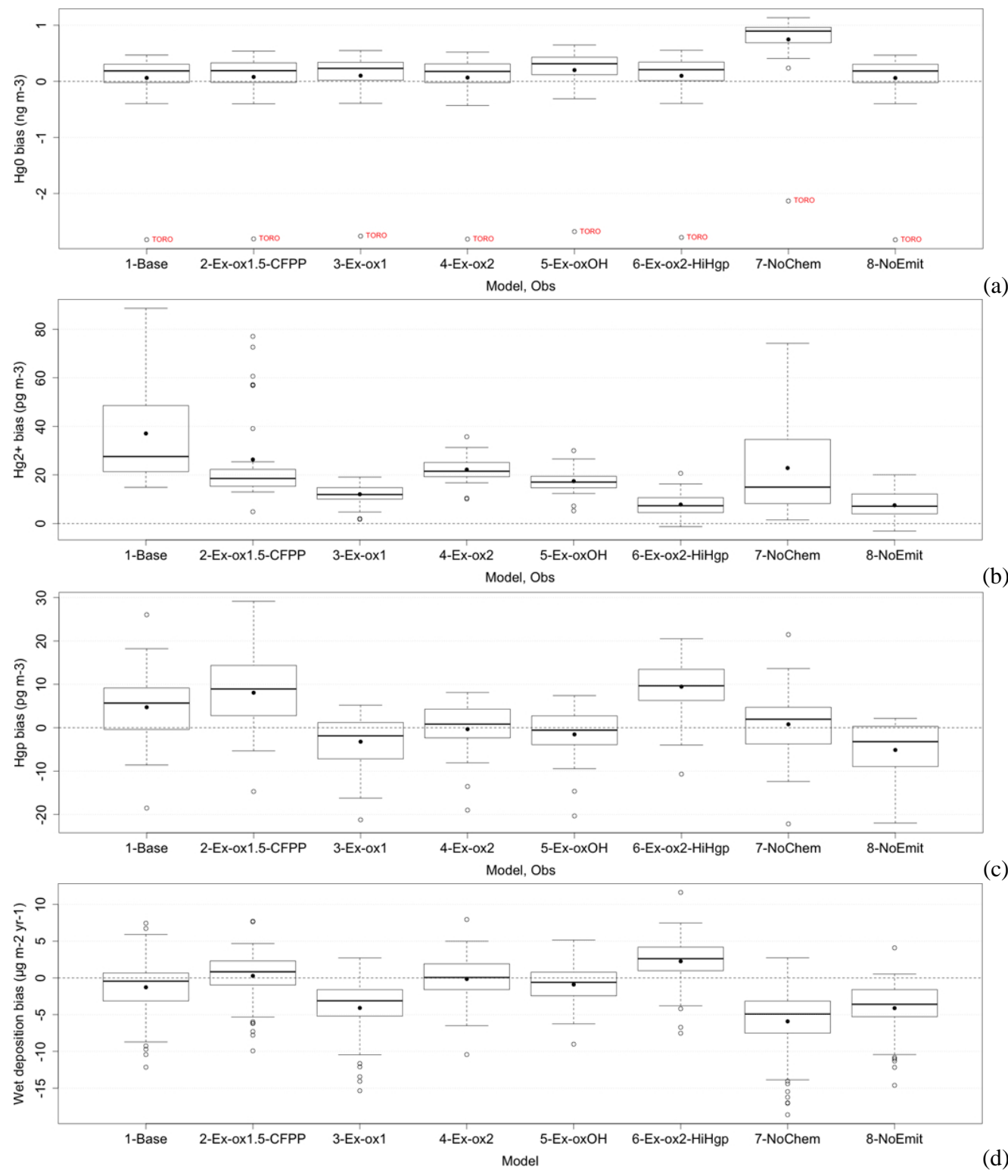

Fig. 4. Spread of yearly bias for different model runs. For a detailed model run description, see Table 2. (a) $\mathrm{Hg}^{0}$, (b) $\mathrm{Hg}^{2+}$, (c) $\mathrm{Hg}_{\mathrm{p}}$, (d) wet deposition.

produced $\mathrm{Hg}^{2+}$ and $\mathrm{Hg}_{\mathrm{p}}$ concentrations are found to be very uniform across the domain. The wet deposition fluxes are underestimated in both cases and lack variation compared to measurements. A point to note here is that while both $\mathrm{Hg}^{2+}$ and $\mathrm{Hg}_{\mathrm{p}}$ mean concentrations are simulated to be higher in the NoChem experiment compared to the NoEmit experiment, the wet deposition is simulated to be markedly lower in the NoChem experiment compared to the NoEmit experiment. This is because the emissions increase $\mathrm{Hg}^{2+}$ in the boundary layer, where it can be readily dry-deposited; however chemistry produces $\mathrm{Hg}^{2+}$ aloft that is scavenged into clouds and wet-deposited. These experiments suggest that spatial distribution of ambient $\mathrm{Hg}^{2+}$ concentrations is more likely to be generated by slow oxidative processes, whereas $\mathrm{Hg}_{\mathrm{p}}$ species is produced both through emission and chemistry. Based on the no chemistry and no emission experiments, it can be inferred that the variability in $\mathrm{Hg}^{2+}$ concentrations in base simulation is mostly due to the primary emissions of $\mathrm{Hg}^{2+}$, which is higher compared to measurements. Next experiment (Ex-ox1), where the emission ratios were modified to $90: 8: 2\left(\mathrm{Hg}^{0}: \mathrm{Hg}^{2+}: \mathrm{Hg}_{\mathrm{p}}\right)$, is seen to produce mean $\mathrm{Hg}^{2+}$ concentrations higher by a factor of two compared to the observed mean; however median $\mathrm{Hg}_{\mathrm{p}}$ concentrations are slightly underpredicted. Although the bias in $\mathrm{Hg}^{2+}$ and $\mathrm{Hg}_{\mathrm{p}}$ is much smaller, the wet deposition fluxes are significantly underpredicted $\left(-4.3 \mu \mathrm{g} \mathrm{m}^{-2}\right)$. It should be noted that 

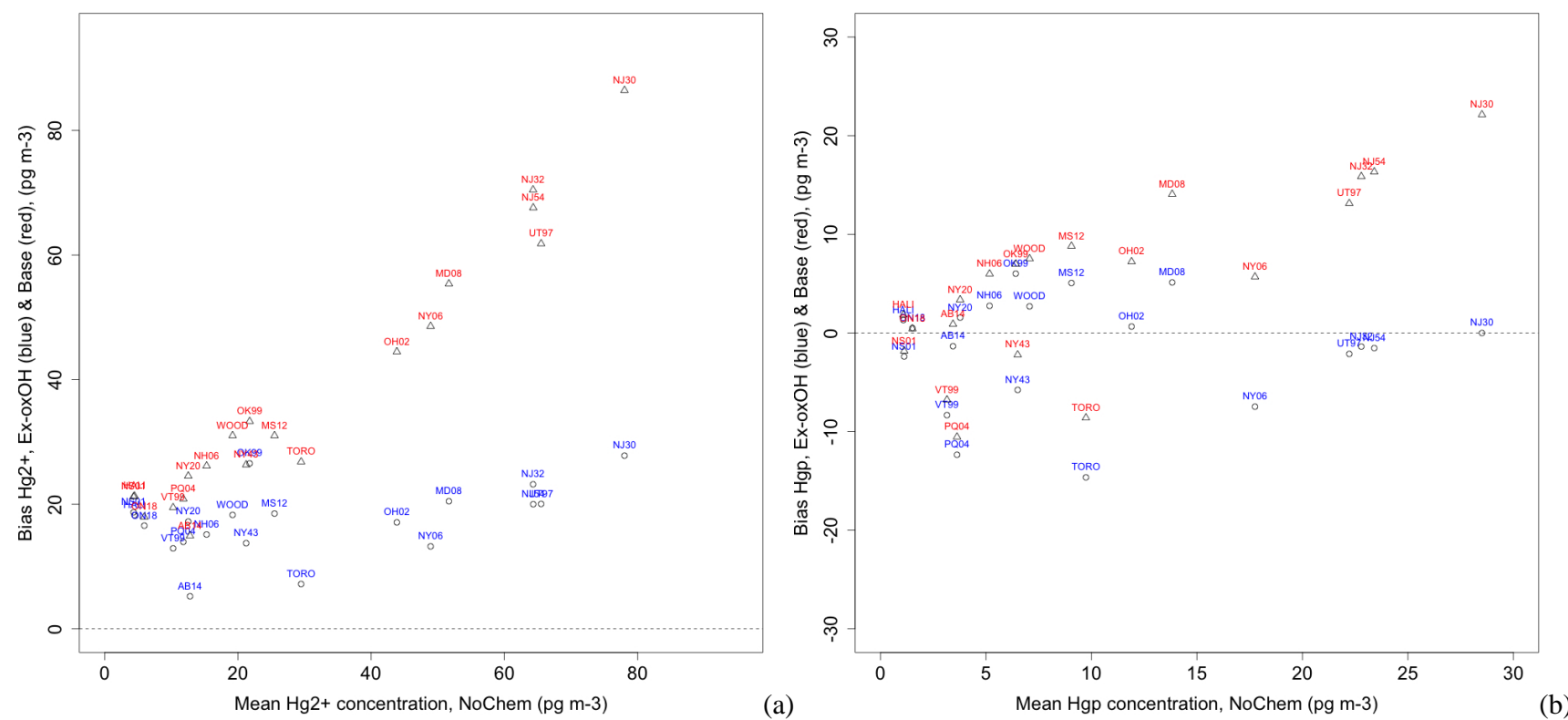

Fig. 5. Model plot of base and Ex-OH bias for (a) $\mathrm{Hg}^{2+}$ and (b) $\mathrm{Hg}_{\mathrm{p}}$ at locations with distance from source. Distribution of $\mathrm{Hg}^{2+}$ in the NoChem experiment (plotted on the x-axis) is determined by the dispersion of these species from the emission sources only. Higher concentrations on the x-axis, therefore, represent proximity to the emission sources. On the left are remote stations, on the right stations close to sources.

the variance is reduced in all three variables, most notably in $\mathrm{Hg}^{2+}$ concentrations, which is in line with observations. The oxidation rate was doubled in the next experiment (Ex-ox2) to see the impact on wet deposition fluxes. This experiment produced wet deposition fluxes comparable to the observed values; however $\mathrm{Hg}^{2+}$ concentrations are increased by $60 \%$, whereas $\mathrm{Hg}_{\mathrm{p}}$ concentrations agree well with the observed values. In the next experiment (Ex-oxOH), $\mathrm{OH}$ was used as the main oxidant and ozone oxidation was not considered. The mean concentrations $\mathrm{Hg}^{0}, \mathrm{Hg}^{2+}$ and $\mathrm{Hg}_{\mathrm{p}}$ were found to be comparable to ozone oxidation experiment with twice the oxidation rate estimated by Hall (1995); however the spatial distribution of the species and wet deposition fluxes, particularly the north-south gradient in wet deposition, was improved when $\mathrm{OH}$ oxidation was used. In Ex-ox 1.5-CFPP experiment, the emission ratios for coal-fired power plants (CFPPs) alone were modified to $90: 5: 5\left(\mathrm{Hg}^{0}: \mathrm{Hg}^{2+}: \mathrm{Hg}_{\mathrm{p}}\right)$; although the bias is reduced for both $\mathrm{Hg}^{2+}$ and $\mathrm{Hg}_{\mathrm{p}}$ concentrations compared to the base run, very high concentrations of $\mathrm{Hg}^{2+}$ at several sites and overestimation of $\mathrm{Hg}_{\mathrm{p}}$ concentrations were simulated. Another experiment (Ex-ox2-HiHgp) was conducted where the $\mathrm{Hg}^{2+} / \mathrm{Hg}_{\mathrm{p}}$ partitioning was modified from $0.75 / 0.25$ to $0.25 / 0.75$ (Table 2). This experiment resulted in overprediction of $\mathrm{Hg}_{\mathrm{p}}$ as well as wet deposition. Overall, $\mathrm{OH}$ as dominant oxidation scheme for $\mathrm{Hg}^{0}$ with $90: 8: 2$ emission ratios for $\mathrm{Hg}^{0}: \mathrm{Hg}^{2+}: \mathrm{Hg}_{\mathrm{p}}$ produced best results. Changing emission ratios to $90: 8: 2$ not only reduces the bias in $\mathrm{Hg}^{2+}$, it also reduces the spread in the bias, decreasing the RMSE sharply by $42 \%$ from 42 to $18 \mathrm{pg} \mathrm{m}^{-3}$ (Fig. 4b), whereas there is no significant change in the spread of the bias in $\mathrm{Hg}_{\mathrm{p}}$ concentrations (RMSE decrease from 10 to $6 \mathrm{pg} \mathrm{m}^{-3}$, i.e. by $40 \%$ ) (Fig. $4 \mathrm{c}$ ). This difference between $\mathrm{Hg}^{2+}$ and $\mathrm{Hg}_{\mathrm{p}}$ is likely due to the fact that primary emissions of $\mathrm{Hg}^{2+}$ are much higher in the original emissions inventory $(40 \%)$ compared to the emissions of $\mathrm{Hg}_{\mathrm{p}}(10 \%)$ used in the base simulation. It is important to note that higher atmospheric concentrations of $\mathrm{Hg}^{2+}$ are needed compared to measured estimates in order to simulate the observed levels of wet deposition fluxes.

The results shown in Figs. 3 and 4 are further analysed in Fig. 5. The $\mathrm{Hg}^{2+}$ and $\mathrm{Hg}_{\mathrm{p}}$ concentrations estimated by the experiment without chemistry (NoChem; $\mathrm{x}$-axis) were plotted against the $\mathrm{Hg}^{2+}$ and $\mathrm{Hg}_{\mathrm{p}}$ concentrations of base simulation (base; red) and $\mathrm{OH}$ oxidation and modified emission ratio experiment (Ex-oxOH; blue). Since distribution of $\mathrm{Hg}^{2+}$ in the NoChem experiment is determined by the dispersion of these species from the emission sources only, higher concentrations on the $\mathrm{x}$-axis represent proximity to the emission sources. Figure 5 clearly illustrates linearly increasing bias in $\mathrm{Hg}^{2+}$ concentrations in the base simulation with increasing proximity to the sources of emissions. Although the $\mathrm{Hg}^{2+}$ bias is significantly reduced with modified emission ratios (blue), it is still found to slightly increase near sources. Lowering the emission of $\mathrm{Hg}_{\mathrm{p}}$ is also found to correct the larger bias in $\mathrm{Hg}_{\mathrm{p}}$ closer to the sources; however the correction leads to negative bias at some of the sites. The negative bias at these sites (including Alert) is perhaps due to improper partitioning between $\mathrm{Hg}^{2+}$ and $\mathrm{Hg}_{\mathrm{p}}$. Impact of lowering the primary emissions of $\mathrm{Hg}^{2+}$ is also pronounced in weekly averaged data for sites close to mercury sources, 

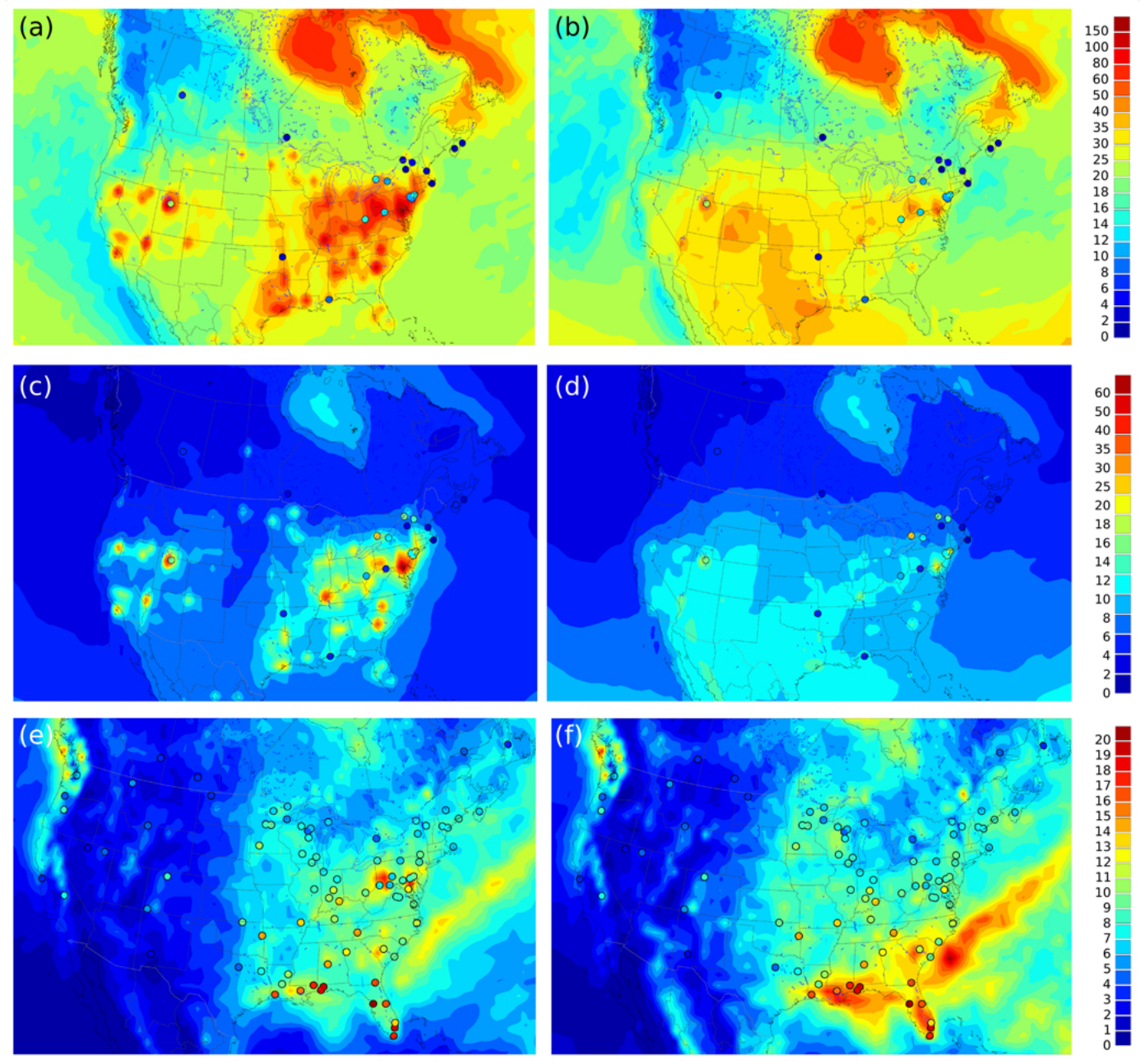

Fig. 6. Model map plots with observations circled. (a) Base run: $\mathrm{Hg}^{2+}$, (b) Ex-oxOH: $\mathrm{Hg}^{2+}$, (c) base run: $\mathrm{Hg}_{\mathrm{p}}$, (d) Ex-oxOH: $\mathrm{Hg}_{\mathrm{p}}$, (e) base run: wet deposition, (f) Ex-oxOH: wet deposition. $\mathrm{Hg}^{2+}$ and $\mathrm{Hgp}$ are yearly averaged in $\mathrm{pg} \mathrm{m}^{-3}$. Units for wet deposition are $\mu \mathrm{g} \mathrm{m}^{-2} \mathrm{yr}^{-1}$.

such as NJ54 and NJ30. The bias is lowered from by $29 \%$ from 68 to $20 \mathrm{pg} \mathrm{m}^{-3}$ for $\mathrm{Hg}^{2+}$, and the unbiased root mean square error (URMSE) drops by $58 \%$ from 19 to $11 \mathrm{pg} \mathrm{m}^{-3}$ for $\mathrm{Hg}^{2+}$ at the $\mathrm{NJ} 54$ site, which has a mean $\mathrm{Hg}^{2+}$ concentration of $65 \mathrm{pg} \mathrm{m}^{-3}$. Thus, not only yearly means, but also temporal variations from weekly averaged data are markedly improved.

Figure 6 illustrates the spatial pattern of $\mathrm{Hg}^{2+}, \mathrm{Hg}_{\mathrm{p}}$ and wet deposition for the base run and the Ex-oxOH run with $90 \% \mathrm{Hg}^{0}$ emissions and $\mathrm{OH}$ oxidation scheme. $\mathrm{Hg}^{2+}$ is noticeably high in the base run in the vicinity of sources compared to the observed values. The Ex-oxOH run is clearly seen to be markedly improved. The most notable improvement is seen in the wet deposition, which has a N-S gradient in the observations. The base run produces very high wet deposition fluxes in the vicinity of sources, whereas this discrepancy is corrected when most $\mathrm{Hg}$ is assumed to be emitted as $\mathrm{Hg}^{0}(90 \%)$. The $\mathrm{N}-\mathrm{S}$ gradient is reproduced well in the Ex-oxOH experiment. This is also the case with simulation using ozone as the main oxidant. $\mathrm{N}-\mathrm{S}$ gradient and high wet deposition fluxes in the southeastern United States are a combination of chemically produced $\mathrm{Hg}^{2+}$ in the free troposphere, gradient in precipitation and scavenging of $\mathrm{Hg}^{2+}$ by high cumulus clouds (Selin and Jacob, 2008). These results suggest that $\mathrm{Hg}^{2+}$ is dominantly produced by chemistry, and perhaps aerosol distribution in the atmosphere that would control the partitioning between the $\mathrm{Hg}^{2+}$ and $\mathrm{Hg}_{\mathrm{p}}$ concentrations and does not seem to be dependent on primary emissions. Since wet deposition is generated through the scavenging of oxidized mercury species and is known to have lower measurement uncertainties compared to the $\mathrm{Hg}^{2+}$ and $\mathrm{Hg}_{\mathrm{p}}$ measurements, good agreement between observed and modelled mean fluxes and spatial distribution of wet deposition suggest that atmospheric concentrations of $\mathrm{Hg}^{2+}$ should be higher than currently estimated by the observations. 


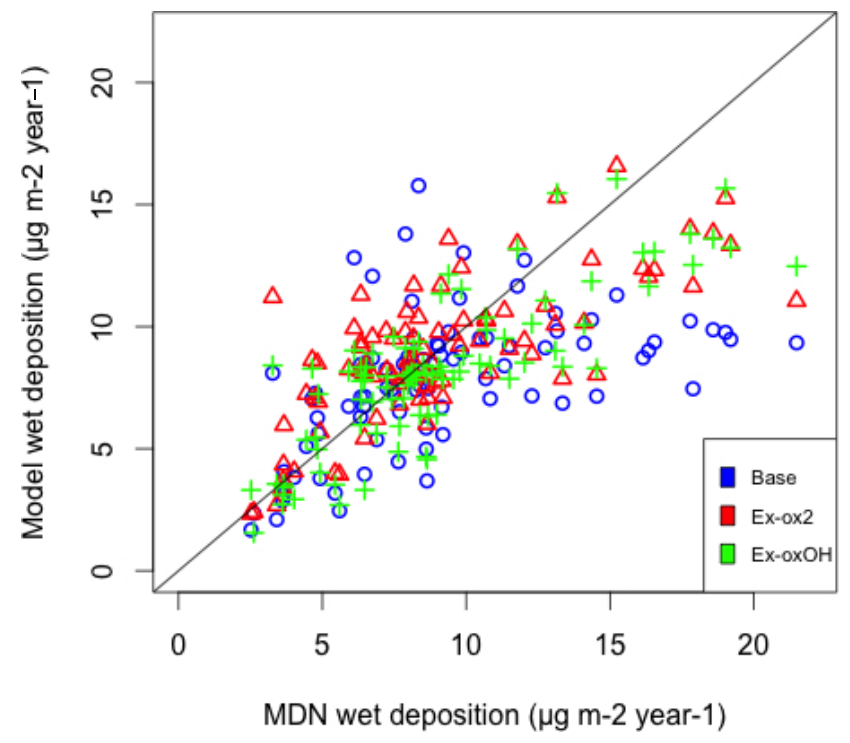

Fig. 7. Yearly averages (2005) of modelled wet deposition concentration plotted against MDN wet deposition measurements.

Wet deposition occurs by the scavenging of the oxidized mercury in and below cloud hydrometeors. Measured wet deposition fluxes are currently considered to be accurate within $20 \%$ (Prestbo and Gay, 2009). Figure 7 presents the scatter plot of annual wet deposition flux for 2005 between observed (MDN) and three model runs (base, Ex-ox2 and ExoxOH). The intercept $(i)$, slope $(m)$ and correlation coefficient $\left(r^{2}\right)$ improved from base run $(i=4.76, m=0.33$, $\left.r^{2}=0.26\right)$ to $\operatorname{Ex}-0 x 2\left(i=4.36, m=0.50, r^{2}=0.53\right)$ to ExoxOH $\left(i=2.63, m=0.61, r^{2}=0.66\right)$. Comparison of the monthly wet deposition fluxes for the three model runs (base, Ex-ox2 and Ex-oxOH) with MDN reveals that using the $\mathrm{OH}$ oxidation chemistry in conjunction with anthropogenic emissions as mostly $\mathrm{Hg}^{0}$ species improves the seasonal cycle throughout the year particularly in the northeast and southeast North America (Fig. 8). Stations used in the validation are mapped in Fig. 1, and a detailed list is given in Appendix Table A1.

\section{Conclusions}

The presented study provides a detailed analysis of uncertainties associated with oxidized mercury measurements and modelling for 21 sampling sites and a total of 41 yearly data sets acquired between 2002 and 2010 throughout North America. Measurement uncertainties underestimating $\mathrm{Hg}^{2+}$ concentrations are $86 \%$ and $36 \%$ for uncertainties yielding higher or lower concentrations. Anthropogenic emission uncertainties are $106 \%$ for $\mathrm{Hg}^{2+}$. Individual contributions to uncertainties evaluated were the underestimation of reactive mercury due to interference of ozone (up to $50 \%$ ) and variations of coal burned in power plants $(100 \%)$. Also, published

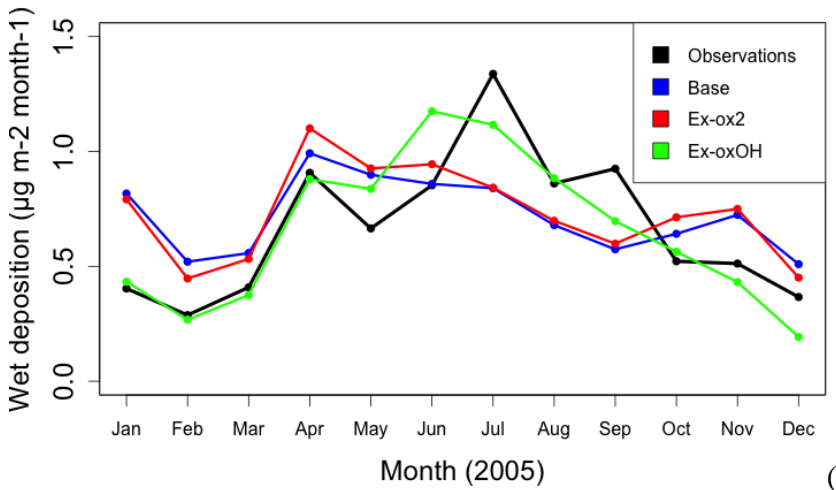

(a)

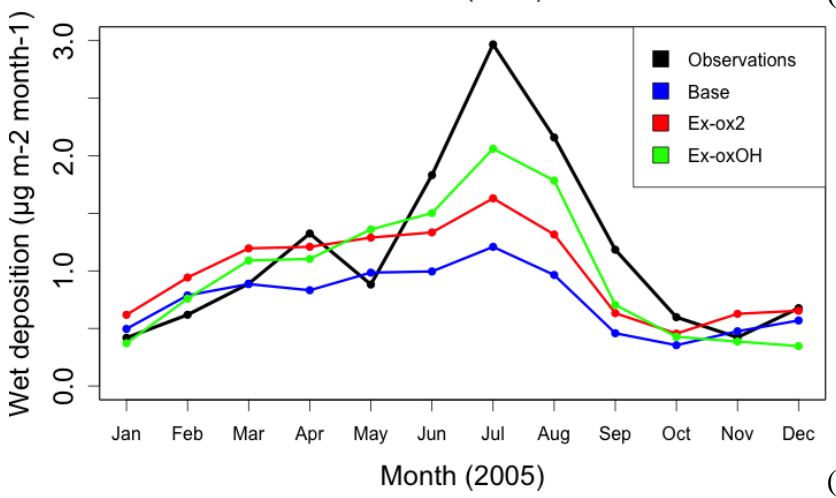

(b)

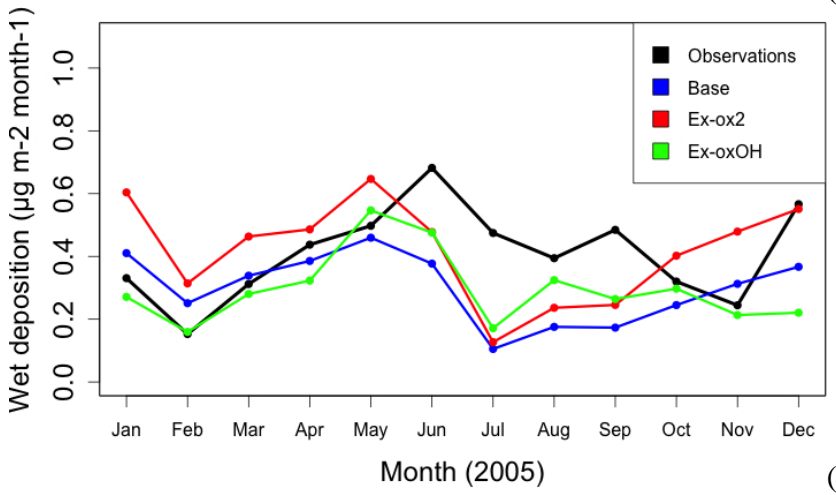

(c)

Fig. 8. Comparison of seasonal model estimates with MDN measurement data, all monthly means, for continental regions in North America. (a) Northeast (49 sites) and (b) southeast (24 sites) are divided by $36^{\circ} \mathrm{N}$. (c) The western region represents 15 sites from $100^{\circ} \mathrm{W}$. Stations are mapped in Fig. 1, and a detailed list is given in Appendix Table A1.

data from co-located measurements show differences of up to $40 \%$.

Model-related overestimation of reactive mercury species $\left(\mathrm{Hg}^{2+}\right.$ and $\left.\mathrm{Hg}_{\mathrm{p}}\right)$ is found to be significantly related to overestimation of oxidized $\mathrm{Hg}$ in emission inventories and/or inplume reduction. A marked reduction of the URMSE by $42 \%$ for $\mathrm{Hg}^{2+}$ and $40 \%$ for $\mathrm{Hg}_{\mathrm{p}}$ was achieved when the ratio of emissions of $\mathrm{Hg}^{0}: \mathrm{Hg}^{2+}: \mathrm{Hg}_{\mathrm{p}}$ was changed from $50: 40: 10$ (as specified in the original inventories) to 90 : $8: 2$. Improvements were especially significant for sites near sources (e.g. New Jersey), where bias values dropped by 
up to $70 \%$ (68 to $20 \mathrm{pg} \mathrm{m}^{-3}$ ) (NJ54) and 88 to $25 \mathrm{pg} \mathrm{m}^{-3}$ (NJ30). Furthermore, wet deposition was found to be better simulated using $\mathrm{OH}$ as the main oxidant compared to $\mathrm{O}_{3}$ in North America. As a consequence identified uncertainties for model calculations, uncertainties in measurement methodology and emission inventories appear to provide exhaustive leads to close the gap between model estimates and observations. The ratio of $\mathrm{Hg}^{0}, \mathrm{Hg}^{2+}$ and $\mathrm{Hg}_{\mathrm{p}}$ in the emission inventories, measurements of surface air concentrations of oxidized $\mathrm{Hg}$ and measurements of wet deposition are found to be inconsistent with each other in the vicinity of emission sources. Current speciation of $\mathrm{Hg}$ emissions suggests significantly high concentrations of $\mathrm{Hg}^{2+}$ in air and in precipitation in the vicinity of emission sources; however, measured air concentrations of $\mathrm{Hg}^{2+}$ and measured concentrations of $\mathrm{Hg}$ in precipitation are not found to be significantly elevated in the vicinity of emission sources compared to the remote regions. Major questions regarding plume chemistry and atmospheric mercury reduction reactions in the gas and aqueous phases and heterogeneous chemistry remain. More reliable measurements of $\mathrm{Hg}^{2+}$ and $\mathrm{Hg}_{\mathrm{p}}$ concentrations and product identification of atmospheric $\mathrm{Hg}$ species are required to test $\mathrm{Hg}$ chemical mechanisms in the models.

Table A1. Station ID and geographic location of validation stations discussed in Fig. 9. Unlabelled blue dots in Fig. 1 correspond to these stations as well.

\begin{tabular}{|c|c|c|c|}
\hline Site & Site Name & $\begin{array}{l}\text { Latitude } \\
\left({ }^{\circ} \mathrm{N}\right)\end{array}$ & $\begin{array}{l}\text { Longitude } \\
\left({ }^{\circ} \mathrm{W}\right)\end{array}$ \\
\hline $\mathrm{AB} 13$ & Henry Kroeger & 51.4242 & -110.8325 \\
\hline AL02 & Delta Elementary & 30.7905 & -87.8497 \\
\hline AL03 & Centreville & 32.9035 & -87.2499 \\
\hline AL24 & Bay Road & 30.4746 & -88.1411 \\
\hline AZ02 & Sycamore Canyon & 35.1406 & -111.9692 \\
\hline CA72 & San Jose & 37.4276 & -122.0624 \\
\hline CA75 & $\begin{array}{l}\text { Sequoia National Park } \\
\text { - Giant Forest }\end{array}$ & 36.5661 & -118.7776 \\
\hline $\mathrm{CO} 97$ & $\begin{array}{l}\text { Buffalo Pass - } \\
\text { Summit Lake }\end{array}$ & 40.5383 & -106.6766 \\
\hline CO99 & $\begin{array}{l}\text { Mesa Verde National } \\
\text { Park - Chapin Mesa }\end{array}$ & 37.1981 & -108.4903 \\
\hline FL04 & Andytown & 26.1667 & -80.5000 \\
\hline FL05 & $\begin{array}{l}\text { Chassahowitzka } \\
\text { National Wildlife } \\
\text { Refuge }\end{array}$ & 28.7486 & -82.5551 \\
\hline FL11 & $\begin{array}{l}\text { Everglades National } \\
\text { Park - Research } \\
\text { Center }\end{array}$ & 25.3900 & -80.6800 \\
\hline FL32 & Orlando & 28.5926 & -81.1904 \\
\hline FL34 & $\begin{array}{l}\text { Everglades Nutrient } \\
\text { Removal Project }\end{array}$ & 26.6556 & -80.3972 \\
\hline GA09 & $\begin{array}{l}\text { Okefenokee National } \\
\text { Wildlife Refuge }\end{array}$ & 30.7403 & -82.1286 \\
\hline
\end{tabular}

Table A1. Continued.

\begin{tabular}{|c|c|c|c|}
\hline Site & Site Name & $\begin{array}{l}\text { Latitude } \\
\left({ }^{\circ} \mathrm{N}\right)\end{array}$ & $\begin{array}{l}\text { Longitude } \\
\left({ }^{\circ} \mathrm{W}\right)\end{array}$ \\
\hline GA40 & Yorkville & 33.9311 & -85.0461 \\
\hline HD01 & Huejutla & 21.1583 & -98.3706 \\
\hline IL11 & Bondville & 40.0528 & -88.3719 \\
\hline IN20 & Roush Lake & 40.8401 & -85.4639 \\
\hline IN21 & Clifty Falls State Park & 38.7622 & -85.4202 \\
\hline IN26 & $\begin{array}{l}\text { Fort Harrison State } \\
\text { Park }\end{array}$ & 39.8583 & -86.0208 \\
\hline IN28 & Bloomington & 39.1464 & -86.6133 \\
\hline IN34 & $\begin{array}{l}\text { Indiana Dunes } \\
\text { National Lakeshore }\end{array}$ & 41.6318 & -87.0881 \\
\hline KY10 & $\begin{array}{l}\text { Mammoth Cave } \\
\text { National Park - } \\
\text { Houchin Meadow }\end{array}$ & 37.1317 & -86.1480 \\
\hline LA05 & Lake Charles & 30.1746 & -93.1717 \\
\hline LA10 & Chase & 32.0970 & -91.7110 \\
\hline LA23 & Alexandria & 31.1698 & -92.3971 \\
\hline LA28 & Hammond & 30.5031 & -90.3769 \\
\hline MA01 & $\begin{array}{l}\text { North Atlantic } \\
\text { Coastal Lab }\end{array}$ & 41.9758 & -70.0247 \\
\hline MD08 & Piney Reservoir & 39.7053 & -79.0122 \\
\hline MD99 & Beltsville & 39.0280 & -76.8171 \\
\hline ME00 & Caribou & 46.8675 & -68.0134 \\
\hline ME02 & Bridgton & 44.1075 & -70.7289 \\
\hline ME09 & Greenville Station & 45.4891 & -69.6647 \\
\hline ME96 & $\begin{array}{l}\text { Casco Bay - } \\
\text { Wolfe's Neck Farm }\end{array}$ & 43.8325 & -70.0645 \\
\hline ME98 & $\begin{array}{l}\text { Acadia National Park } \\
\text { - McFarland Hill }\end{array}$ & 44.3772 & -68.2608 \\
\hline MI48 & $\begin{array}{l}\text { Seney National } \\
\text { Wildlife Refuge - } \\
\text { Headquarters }\end{array}$ & 46.2875 & -85.9541 \\
\hline MN16 & $\begin{array}{l}\text { Marcell Experimental } \\
\text { Forest }\end{array}$ & 47.5311 & -93.4686 \\
\hline MN18 & Fernberg & 47.9464 & -91.4961 \\
\hline MN22 & $\begin{array}{l}\text { Mille Lacs Band of } \\
\text { Ojibwe }\end{array}$ & 46.2053 & -93.7589 \\
\hline MN23 & Camp Ripley & 46.2494 & -94.4972 \\
\hline MN27 & Lamberton & 44.2369 & -95.3010 \\
\hline MO46 & $\begin{array}{l}\text { Mingo National } \\
\text { Wildlife Refuge }\end{array}$ & 36.9716 & -90.1433 \\
\hline MS22 & Oak Grove & 30.9850 & -88.9319 \\
\hline MT05 & $\begin{array}{l}\text { Glacier National Park } \\
\text { - Fire Weather Station }\end{array}$ & 48.5103 & -113.9958 \\
\hline $\mathrm{NC} 08$ & Waccamaw State Park & 34.2592 & -78.4777 \\
\hline $\mathrm{NC} 42$ & Pettigrew State Park & 35.7373 & -76.5149 \\
\hline ND01 & $\begin{array}{l}\text { Lostwood National } \\
\text { Wildlife Refuge }\end{array}$ & 48.6424 & -102.4022 \\
\hline NF09 & Cormak & 49.3214 & -57.3931 \\
\hline NM10 & Caballo & 33.0625 & -107.2917 \\
\hline NS01 & $\begin{array}{l}\text { Kejimkujik National } \\
\text { Park }\end{array}$ & 44.4328 & -65.2056 \\
\hline NV02 & Lesperance Ranch & 41.5033 & -117.4989 \\
\hline
\end{tabular}


Table A1. Continued.

\begin{tabular}{|c|c|c|c|}
\hline Site & Site Name & $\begin{array}{l}\text { Latitude } \\
\left({ }^{\circ} \mathrm{N}\right)\end{array}$ & $\begin{array}{l}\text { Longitude } \\
\left({ }^{\circ} \mathrm{W}\right)\end{array}$ \\
\hline NV99 & Gibbs Ranch & 41.5713 & -115.2117 \\
\hline NY20 & Huntington Wildlife & 43.9731 & -74.2231 \\
\hline NY68 & Biscuit Brook & 41.9936 & -74.5031 \\
\hline OA02 & Puerto Ángel & 15.6500 & -96.4833 \\
\hline $\mathrm{OH} 02$ & Athens Super Site & 39.3078 & -82.1182 \\
\hline OK15 & Newkirk & 36.9564 & -97.0335 \\
\hline OK99 & Stilwell & 35.7514 & -94.6717 \\
\hline ON07 & Egbert & 44.2339 & -79.7917 \\
\hline OR01 & Beaverton & 45.4704 & -122.8151 \\
\hline OR10 & $\begin{array}{l}\text { H. J. Andrews } \\
\text { Experimental Forest }\end{array}$ & 44.2133 & -122.2533 \\
\hline PA00 & Arendtsville & 39.9231 & -77.3078 \\
\hline PA13 & $\begin{array}{l}\text { Allegheny Portage } \\
\text { Railroad National } \\
\text { Historic Site }\end{array}$ & 40.4570 & -78.5600 \\
\hline PA30 & Erie & 42.1558 & -80.1134 \\
\hline PA37 & Waynesburg & 39.8161 & -80.2850 \\
\hline PA47 & Millersville & 39.9900 & -76.3862 \\
\hline PA60 & Valley Forge & 40.1166 & -75.8833 \\
\hline PA72 & Milford & 41.3273 & -74.8199 \\
\hline PA90 & Hills Creek State Park & 41.8043 & -77.1903 \\
\hline PQ04 & St. Anicet & 45.2000 & -74.0333 \\
\hline PQ05 & Mingan & 50.2667 & -64.2333 \\
\hline $\mathrm{SC} 05$ & $\begin{array}{l}\text { Cape Romain } \\
\text { National Wildlife } \\
\text { Refuge }\end{array}$ & 32.9419 & -79.6591 \\
\hline SC19 & Congaree Swamp & 33.8145 & -80.7809 \\
\hline SK12 & Bratt's Lake BSRN & 50.2003 & -104.7111 \\
\hline TN11 & $\begin{array}{l}\text { Great Smoky } \\
\text { Mountains National } \\
\text { Park - Elkmont }\end{array}$ & 35.6645 & -83.5903 \\
\hline TX21 & Longview & 32.3786 & -94.7117 \\
\hline TX50 & Fort Worth & 32.6932 & -97.2496 \\
\hline VA08 & Culpeper & 38.4222 & -78.1044 \\
\hline VA28 & $\begin{array}{l}\text { Shenandoah National } \\
\text { Park - Big Meadows }\end{array}$ & 38.5225 & -78.4358 \\
\hline VA98 & Harcum & 37.5312 & -76.4928 \\
\hline VT99 & Underhill & 44.5283 & -72.8684 \\
\hline WA18 & Seattle/NOAA & 47.6843 & -122.2588 \\
\hline WI08 & Brule River & 46.7466 & -91.6055 \\
\hline WI09 & Popple River & 45.7964 & -88.3994 \\
\hline WI10 & Potawatomi & 45.5633 & -88.8082 \\
\hline WI22 & Milwaukee & 43.0752 & -87.8843 \\
\hline WI31 & Devil's Lake & 43.4352 & -89.6801 \\
\hline WI32 & Middle Village & 44.9308 & -88.7550 \\
\hline WI36 & Trout Lake & 46.0528 & -89.6531 \\
\hline WI99 & Lake Geneva & 42.5792 & -88.5006 \\
\hline WY08 & $\begin{array}{l}\text { Yellowstone National } \\
\text { Park - Tower Falls }\end{array}$ & 44.9166 & -110.4203 \\
\hline
\end{tabular}

Acknowledgements. The authors kindly acknowledge C. Banic (Environment Canada), D. Deeds (McGill University), C. Eckley (Environment Canada), M. Engle (USGS), E. Prestbo (Tekran Inc.), and M. Tate (USGS) for insightful discussions on plume chemistry, aerosol chemistry and atmospheric reduction processes of mercury species. We extend thanks to all data providers listed in Table 4. The authors would like to thank the reviewers (P. Pongprueksa and anonymous) for their insightful comments that led to significant improvements in the manuscript.

Edited by: J. H. Seinfeld

\section{References}

AMAP: AMAP Assessment 2011: Mercury in the Arctic, Arctic Monitoring and Assessment Programme (AMAP), Oslo, Norway, xiv + 193 pp., 2011.

Amos, H. M., Jacob, D. J., Holmes, C. D., Fisher, J. A., Wang, Q., Yantosca, R. M., Corbitt, E. S., Galarneau, E., Rutter, A. P., Gustin, M. S., Steffen, A., Schauer, J. J., Graydon, J. A., St Louis, V. L., Talbot, R. W., Edgerton, E. S., Zhang, Y., and Sunderland, E. M.: Gas-particle partitioning of atmospheric $\mathrm{Hg}(\mathrm{II})$ and its effect on global mercury deposition, Atmos. Chem. Phys., 12, 591-603, doi:10.5194/acp-12-591-2012, 2012.

Ariya, P. A., Khalizov, A., and Gidas, A.: Reactions of gaseous mercury with atomic and molecular halogens: kinetics, product studies, and atmospheric implications, J. Phys. Chem. A, 106, 73107320, doi:10.1021/jp020719o, 2002.

Aspmo, K., Gauchard, P. A., Steffen, A., Temme, C., Berg, T., Bahlmann, E., Banic, C., Dommergue, A., Ebinghaus, R., Ferrari, C., Pirrone, N., Sprovieri, F., and Wibetoe, G.: Measurements of atmospheric mercury species during an international study of mercury depletion events at Ny-Alesund, Svalbard, spring 2003. How reproducible are our present methods?, Atmos. Environ., 39, 7607-7619, doi:10.1016/j.atmosenv.2005.07.065, 2005.

Aucott, M. L., Caldarelli, A. D., Zsolway, R. R., Pietarinen, C. B., and England, R.: Ambient elemental, reactive gaseous, and particle-bound mercury concentrations in New Jersey, US: Measurements and associations with wind direction, Environ. Monit Assess., 158, 295-306, doi:10.1007/s10661-008-0583-0, 2009.

Author Collective: Findings and recommendations from a workshop on "reducing the uncertainty in 2 measurements of atmospheric Hg" held at the University of Washington 3, 23-25 October 2008, Report of the Uncertainty Workshop, 1-17, 2009.

Bloom, N. and Fitzgerald, W. F.: Determination of volatile mercury species at the picogram level by low-temperature gaschromatography with cold-vapor atomic fluorescence detection, Anal. Chim. Acta, 208, 151-161, doi:10.1016/S00032670(00)80743-6, 1988.

Brooks, S., Luke, W., Cohen, M., Kelly, P., Lefer, B., and Rappenglueck, B.: Mercury species measured atop the moody tower tramp site, Houston, Texas, Atmos. Environ., 44, 4045-4055, doi:10.1016/j.atmosenv.2009.02.009, 2010.

Brown, R. J. C., Brown, A. S., Yardley, R. E., Corns, W. T., and Stockwell, P. B.: A practical uncertainty budget for ambient mercury vapour measurement, Atmos. Environ., 42, 2504-2517, doi:10.1016/j.atmosenv.2007.12.012, 2008. 
Caldwell, C. A., Swartzendruber, P., and Prestbo, E.: Concentration and dry deposition of mercury species in arid South Central New Mexico (2001-2002), Environ. Sci. Technol., 40, 75357540, doi:10.1021/es0609957, 2006.

Calvert, J. G. and Lindberg, S. E.: Mechanisms of mercury removal by $\mathrm{O}_{3}$ and $\mathrm{OH}$ in the atmosphere, Atmos. Environ., 39, 33553367, doi:10.1016/j.atmosenv.2005.01.055, 2005.

Choi, H.-D., Huang, J., Mondal, S., and Holsen, T. M.: Variation in concentrations of three mercury $(\mathrm{Hg})$ forms at a rural and a suburban site in New York State, Sci. Total Environ., 448, 96106, doi:10.1016/j.scitotenv.2012.08.052, 2012.

Côté, J., Desmarais, J.-G., Gravel, S., Méthot, A., Patoine, A., Roch, M., and Staniforth, A.: The operational CMC-MRB Global Environmental Multiscale (GEM) model. Part II: Results, Mon Weather Rev., 126, 1397-1418, doi:10.1175/15200493(1998)126<1397:TOCMGE>2.0.CO;2, 1998a.

Côté, J., Gravel, S., Méthot, A., Patoine, A., Roch, M., and Staniforth, A.: The operational CMC-MRB Global Environmental Multiscale (GEM) model. Part I: Design considerations and formulation, Mon. Weather Rev., 126, 1373-1395, doi:10.1175/1520-0493(1998)126;1373:TOCMGE $; 2.0 . C O ; 2$, 1998b.

Cremer, D., Kraka, E., and Filatov, M.: Bonding in Mercury Molecules Described by the Normalized Elimination of the Small Component and Coupled Cluster Theory, Chem. Phys. Chem., 9, 2510-2521, doi:10.1002/cphc.200800510, 2008.

Dastoor, A. P., Davignon, D., Theys, N., Van Roozendael, M., Steffen, A., and Ariya, P. A.: Modeling dynamic exchange of gaseous elemental mercury at polar sunrise, Environ. Sci. Technol., 42, 5183-5188, doi:10.1021/es800291w, 2008.

Deeds, D. A., Banic C., Lu, J., and Daggupaty, S.: Mercury partitioning in a coal-fired power plant plume: An aircraftbased study of emissions from the 3,640 MW Nanticoke generating station, Ontario, Canada, J. Geophys. Res.-Atmos, doi:10.1002/jgrd.50349, in press, 2013.

Dibble, T. S., Zelie, M. J., and Mao, H.: Thermodynamics of reactions of $\mathrm{ClHg}$ and $\mathrm{BrHg}$ radicals with atmospherically abundant free radicals, Atmos. Chem. Phys., 12, 10271-10279, doi:10.5194/acp-12-10271-2012, 2012.

Donohoue, D. L., Bauer, D., Cossairt, B., and Hynes, A. J.: Temperature and pressure dependent rate coefficients for the reaction of hg with br and the reaction of $\mathrm{Br}$ with $\mathrm{Br}$ : A pulsed laser photolysis-pulsed laser induced fluorescence study, J. Phys. Chem. A, 110, 6623-6632, doi:10.1021/jp054688j, 2006.

Durnford, D., Dastoor, A., Figueras-Nieto, D., and Ryjkov, A.: Long range transport of mercury to the Arctic and across Canada, Atmos. Chem. Phys., 10, 6063-6086, doi:10.5194/acp-10-60632010, 2010.

Edgerton, E. S., Hartsell, B. E., and Jansen, J. J.: Mercury speciation in coal-fired power plant plumes observed at three surface sites in the Southeastern US, Environ. Sci. Technol., 40, 4563-4570, doi:10.1021/es0515607, 2006.

Engle, M. A., Tate, M. T., Krabbenhoft, D. P., Kolker, A., Olson, M. L., Edgerton, E. S., DeWild, J. F., and McPherson, A. K.: Characterization and cycling of atmospheric mercury along the central US Gulf Coast, Appl. Geochem., 23, 419-437, doi:10.1016/j.apgeochem.2007.12.024, 2008.

Engle, M. A., Tate, M. T., Krabbenhoft, D. P., Schauer, J. J., Kolker, A., Shanley, J. B., and Bothner, M. H.: Comparison of atmo- spheric mercury speciation and deposition at nine sites across central and eastern North America, J. Geophys. Res.-Atmos., 115, D18306, doi:10.1029/2010JD014064, 2010.

Fitzgerald, W. F.: Is mercury increasing in the atmosphere - the need for an atmospheric mercury network (AMNet), Water Air Soil Poll., 80, 245-254, doi:10.1007/BF01189674, 1995.

Fu, X. W., Feng, X. B., Zhu, W. Z., Zheng, W., Wang, S. F., and Lu, J. Y.: Total particulate and reactive gaseous mercury in ambient air on the eastern slope of the Mt. Gongga area, China. Appl Geochem., 23, 408-418, doi:10.1016/j.apgeochem.2007.12.018, 2008.

Gabriel, M. C., Williamson, D. G., Brooks, S., and Lindberg, S.: Atmospheric speciation of Southeastern mercury in two contrasting US airsheds, Atmos. Environ., 39, 4947-4958, doi:10.1016/j.atmosenv.2005.05.003, 2005.

Goodsite, M. E., Plane, J. M. C., and Skov, H.: A theoretical study of the oxidation of $\mathrm{Hg}$ to $\mathrm{HgBr}$ in the troposphere, Environ. Sci. Technol., 38, 1772-1776, doi:10.1021/es034680s, 2004.

Hall, B.: The gas-phase oxidation of elemental mercury by ozone, Water Air Soil Poll., 80, 301-315, 1995.

Hall, B. D., Olson, M. L., Rutter, A. P., Frontiera, R. R., Krabbenhoft, D. P., Gross, D. S., Yuen, M., Rudolph, T. M., and Schauer, J. J.: Atmospheric mercury speciation in Yellowstone National Park, Sci. Total. Environ., 367, 354-366, doi:10.1016/j.scitotenv.2005.12.007, 2006.

Helsel, D. R.: Less than obvious - statistical treatment of data below the detection limit, Environ. Sci. Technol., 24, 1766-1774, 1990.

Helsel, D. R.: More than obvious: Better methods for interpreting nondetect data, Environ Sci. Technol., 39, 419A-423A, 2005.

Holmes, C. D.: Atmospheric chemistry: Quick cycling of quicksilver, Nat. Geosci., 5, 95-96, doi:10.1038/ngeo1389, 2012.

Holmes, C. D., Jacob, D. J., Corbitt, E. S., Mao, J., Yang, X., Talbot, R., and Slemr, F.: Global atmospheric model for mercury including a theoretical study of the, Atmos. Chem. Phys., 10, 12037-12057, doi:10.5194/acp-10-12037-2010, 2010.

Hsi, H. C., Lee, H. H., Hwang, J. F., and Chen, W.: Mercury speciation and distribution in a 660-megawatt utility boiler in Taiwan firing bituminous coals, J. Air Waste Manage., 60, 514-522, doi:10.3155/1047-3289.60.5.514, 2010.

Huang, J. Y., Choi, H. D., Hopke, P. K., and Holsen, T. M.: Ambient mercury sources in Rochester, NY: Results from principle components analysis (PCA) of mercury monitoring network data, Environ. Sci. Technol., 44, 8441-8445, doi:10.1021/es102744j, 2010.

Hynes, A., Donohoue, D., Goodsite, M., Hedgecock, I., Pirrone, N., and Mason, R.: Our current understanding of major chemical and physical processes affecting mercury dynamics in the atmosphere and at air-water/terrestrial interfaces, in: Mercury Fate and Transport in the Global Atmosphere, edited by: Pirrone, N. and Mason, R. P., chap. 14, Springer, 2009.

Jaffe, D., Prestbo, E., Swartzendruber, P., Weiss-Penzias, P., Kato, S., Takami, A., Hatakeyama, S., and Kajji, Y.: Export of atmospheric mercury from Asia, Atmos. Environ., 39, 3029-3038, doi:10.1016/j.atmosenv.2005.01.030, 2005.

Justino, C. I. L., Rocha-Santos, T. A., and Duarte, A. C.: Sampling and characterization of nanoaerosols in different environments, TRAC-Trend. Anal. Chem., 30, 554-567, doi:10.1016/j.trac.2010.12.002, 2011. 
Keeler, G., Glinsorn, G., and Pirrone, N.: Particulate mercury in the atmosphere - its significance, transport, transformation and sources, Water Air Soil Poll., 80, 159-168, 1995.

Kim, J. H., Park, J. M., Lee, S. B., Pudasainee, D., and Seo, Y. C.: Anthropogenic mercury emission inventory with emission factors and total emission in Korea, Atmos. Environ., 44, 27142721, doi:10.1016/j.atmosenv.2010.04.037, 2010.

Klockow, D., Siemens, V., and Larjava, K.: Application of diffusion separators for measurement of metal emissions, VDI Bericht, 838, 389-400, 1990.

Kocman, D. and Horvat, M.: A laboratory based experimental study of mercury emission from contaminated soils in the river idrijca catchment, Atmos. Chem. Phys., 10, 1417-1426, doi:10.5194/acp-10-1417-2010, 2010.

Kolker, A., Olson, M. L., Krabbenhoft, D. P., Tate, M. T., and Engle, M. A.: Patterns of mercury dispersion from local and regional emission sources, rural central Wisconsin, USA, Atmos. Chem. Phys., 10, 4467-4476, doi:10.5194/acp-10-4467-2010, 2010.

Landis, M. S., Stevens, R. K., Schaedlich, F., and Prestbo, E. M.: Development and characterization of an annular denuder methodology for the measurement of divalent inorganic reactive gaseous mercury in ambient air, Environ. Sci. Technol., 36, 3000-3009, doi:10.1021/es015887t, 2002.

Landis, M., Ryan, J., Oswald, E., Jansen, J., Monroe, L., Walters, J., Levin, L., Ter Schure, A., Laudal, D., and Edgerton, E.: Plant Crist mercury plume study, Air Quality VII, October 2009, Washington DC, 2009.

Li, J., Sommar, J., Wangberg, I., Lindqvist, O., and Wei, S. Q.: Short-time variation of mercury speciation in the urban of Goteborg during GOTE-2005, Atmos. Environ., 42, 8382-8388, doi:10.1016/j.atmosenv.2008.08.007, 2008.

Lindberg, S. E. and Stratton, W. J.: Atmospheric mercury speciation: Concentrations and behavior of reactive gaseous mercury in ambient air, Environ. Sci. Technol., 32, 49-57, doi:10.1021/es970546u, 1998.

Lindberg, S. E., Hanson, P. J., Meyers, T. P., and Kim, K. H.: Air/surface exchange of mercury vapor over forests - the need for a reassessment of continental biogenic emissions, Atmos. Environ., 32, 895-908, doi:10.1016/S1352-2310(97)00173-8, 1998.

Lindberg, S. E., Brooks, S., Lin, C. J., Scott, K. J., Landis, M. S., Stevens, R. K., Goodsite, M., and Richter, A.: Dynamic oxidation of gaseous mercury in the arctic troposphere at polar sunrise, Environ. Sci. Technol., 36, 1245-1256, doi:10.1021/es0111941, 2002.

Lindberg, S., Bullock, R., Ebinghaus, R., Engstrom, D., Feng, X. B., Fitzgerald, W., Pirrone, N., Prestbo, E., and Seigneur, C.: A synthesis of progress and uncertainties in attributing the sources of mercury in deposition, Ambio, 36, 19-32, doi:10.1579/00447447(2007)36[19:ASOPAU]2.0.CO;2, 2007.

Liu, B., Keeler, G. J., Dvonch, J. T., Barres, J. A., Lynam, M. M., Marsik, F. J., and Morgan, J. T.: Temporal variability of mercury speciation in urban air, Atmos. Environ., 41, 1911-1923, doi:10.1016/j.atmosenv.2006.10.063, 2007.

Liu, B., Keeler, G. J., Dvonch, J. T., Barres, J. A., Lynam, M. M., Marsik, F. J., and Morgan, J. T.: Urban-rural differences in atmospheric mercury speciation, Atmos. Environ., 44, 2013-2023, doi:10.1016/j.atmosenv.2010.02.012, 2010.

Liu, N., Qiu, G. G., Landis, M. S., Feng, X. B., Fu, X. W., and Shang, L. H.: Atmospheric mercury species measured in
Guiyang, Guizhou province, Southwest China, Atmos. Res., 100, 93-102, doi:10.1016/j.atmosres.2011.01.002, 2011.

Lohman, K., Seigneur, C., Edgerton, E., and Jansen, J.: Modeling mercury in power plant plumes, Environ. Sci. Technol., 40, 3848-3854, doi:10.1021/es051556v, 2006.

Lyman, S. N. and Gustin, M. S.: Determinants of atmospheric mercury concentrations in Reno, Nevada, USA, Sci. Total Environ., 408, 431-438, doi:10.1016/j.scitotenv.2009.09.045, 2009.

Lyman, S. N., Jaffe, D. A., and Gustin, M. S., Release of mercury halides from $\mathrm{KCl}$ denuders in the presence of ozone, Atmos. Chem. Phys., 10, 8197-8204, doi:10.5194/acp-10-81972010, 2010.

Malcolm, E. G. and Keeler, G. J.: Evidence for a sampling artifact for particulate-phase mercury in the marine atmosphere, Atmos. Environ., 41, 3352-3359, doi:10.1016/j.atmosenv.2006.12.024, 2007.

Manolopoulos, H., Schauer, J. J., Purcell, M. D., Rudolph, T. M., Olson, M. L., Rodger, B., and Krabbenhoft, D. P.: Local and regional factors affecting atmospheric mercury speciation at a remote location, J. Environ. Eng. Sci., 6, 491-501, doi:10.1139/S07-005, 2007.

Mason, R. P.: Mercury emissions from natural processes and their importance in the global mercury cycle, in: Mercury Fate and Transport in the Global Atmosphere, edited by: Mason, R. and Pirrone, N., Boston, MA, Springer US, 173-191, doi:10.1007/978-0-387-93958-2, 2009.

Maynard, A. D. and Aitken, R. J.: Assessing exposure to airborne nanomaterials: Current abilities and future requirements, Nanotoxicology, 1, 26-41, doi:10.1080/17435390701314720, 2007.

Munthe, J., Wangberg, I., Pirrone, N., Iverfeldt, A., Ferrara, R., Ebinghaus, R., Feng, X., Gardfeldt, K., Keeler, G., Lanzillotta, E., Lindberg, S. E., Lu, J., Mamane, Y., Prestbo, E., Schmolke, S., Schroeder, W. H., Sommar, J., Sprovieri, F., Stevens, R. K., Stratton, W., Tuncel, G., and Urba, A.: Intercomparison of methods for sampling and analysis of atmospheric mercury species, Atmos. Environ., 35, 3007-3017, 2001.

Munthe, J., Wangberg, I., Iverfeldt, A., Lindqvist, O., Stromberg, D., Sommar, J., Gardfeldt, K., Petersen, G., Ebinghaus, R., Prestbo, E., Larjava, K., and Siemens, V.: Distribution of atmospheric mercury species in Northern Europe: Final results from the Moe Project, Atmos. Environ., 37, S9-S20, doi:10.1016/S1352-2310(03)00235-8, 2003.

NAD Program: Atmospheric mercury network site operations manual, version 1.0. Operations Manual, 1-36, Retrieved from http: //nadp.isws.illinois.edu (last access: 18 June 2012), 2011.

Niksa, S., Naik, C. V., Berry, M. S., and Monroe, L.: Interpreting enhanced $\mathrm{Hg}$ oxidation with $\mathrm{Br}$ addition at plant miller, Fuel Process Technol., 90, 1372-1377, doi:10.1016/j.fuproc.2009.05.022, 2009.

Pacyna, E. G., Pacyna, J. M., Sundseth, K., Munthe, J., Kindbom, K., Wilson, S., Steenhuisen, F., and Maxson, P.: Global emission of mercury to the atmosphere from anthropogenic sources in 2005 and projections to 2020, Atmos. Environ., 44, 2487-2499, doi:10.1016/j.atmosenv.2009.06.009, 2010.

Pal, B. and Ariya, P. A. A.: Gas-Phase HO' - Initiated Reactions of Elemental Mercury: Kinetics, Product Studies, and Atmospheric Implications, Environ. Sci. Technol., 38, 5555-5566, doi:10.1021/es0494353, 2004. 
Peterson, S. A., Ralston, N. V. C., Peck, D. V., Van, S. J., Robertson, J. D., Spate, V. L., and Morris, J. S.: How might selenium moderate the toxic effects of mercury in stream fish of the Western US?, Environ. Sci. Technol., 43, 3919-3925, doi:10.1021/es803203g, 2009.

Poissant, L., Pilote, M., Xu, X. H., Zhang, H., and Beauvais, C.: Atmospheric mercury speciation and deposition in the bay St. Francois wetlands, J. Geophys. Res.-Atmos., 109, D11301, doi:10.1029/2003JD004364, 2004.

Poissant, L., Pilote, M., Beauvais, C., Constant, P., and Zhang, H. H.: A year of continuous measurements of three atmospheric mercury species (GEM, RGM and Hg-p) in Southern Quebec, Canada, Atmos. Environ., 39, 1275-1287, doi:10.1016/j.atmosenv.2004.11.007, 2005.

Prestbo, E. M. and Gay, D. A.: Wet deposition of mercury in the US and Canada, 1996-2005: Results and analysis of the NADP mercury deposition network (MDN), Atmos. Environ., 43, 42234233, doi:10.1016/j.atmosenv.2009.05.028, 2009.

Raofie, F. and Ariya, P. A.: Kinetics and products study of the reaction of BrO radicals with gaseous mercury, J. Phys. IV, 107, 1119-1121 doi:10.1051/jp4:20030497, 2003.

Rothenberg, S. E., Mckee, L., Gilbreath, A., Yee, D., Connor, M., and $\mathrm{Fu}, \mathrm{X}$. W.: Evidence for short-range transport of atmospheric mercury to a rural, inland site, Atmos. Environ., 44, 1263-1273, doi:10.1016/j.atmosenv.2009.12.032, 2010a.

Rothenberg, S. E., Mckee, L., Gilbreath, A., Yee, D., Connor, M., and Fu, X. W.: Wet deposition of mercury within the vicinity of a cement plant before and during cement plant maintenance, Atmos. Environ., 44, 1255-1262, doi:10.1016/j.atmosenv.2009.12.033, 2010b.

Rutter, A. P. and Schauer, J. J.: The impact of aerosol composition on the particle to gas partitioning of reactive mercury, Environ. Sci. Technol., 41, 3934-3939, doi:10.1021/es062439i, 2007a.

Rutter, A. P. and Schauer, J. J.: The effect of temperature on the gas-particle partitioning of reactive mercury in atmospheric aerosols, Atmos. Environ., 41, 8647-8657, doi:10.1016/j.atmosenv.2007.07.024, 2007b.

Rutter, A. P., Snyder, D. C., Stone, E. A., Schauer, J. J., GonzalezAbraham, R., Molina, L. T., Márquez, C., Cárdenas, B., and de Foy, B.: In situ measurements of speciated atmospheric mercury and the identification of source regions in the Mexico City Metropolitan Area, Atmos. Chem. Phys., 9, 207-220, doi:10.5194/acp-9-207-2009, 2009.

Rutter, A. P., Shakya, K. M., Lehr, R., Schauer, J. J., and Griffin, R. J.: Oxidation of gaseous elemental mercury in the presence of secondary organic aerosols, Atmos. Environ., 59, 86-92, doi:10.1016/j.atmosenv.2012.05.009, 2012.

Ryaboshapko, A., Bullock, O. R., Christensen, J., Cohen, M., Dastoor, A., Ilyin, I., Petersen, G., Syrakov, D., Artz, R. S., Davignon, D., Draxler, R. R., and Munthe, J.: Intercomparison study of atmospheric mercury models: 1 . Comparison of models with short-term measurements, Sci. Total Environ., 376, 228-240, doi:10.1016/j.scitotenv.2007.01.072, 2007a.

Ryaboshapko, A., Bullock, O. R., Christensen, J., Cohen, M., Dastoor, A., Ilyin, I., Petersen, G., Syrakov, D., Travnikov, O., Artz, R. S., Davignon, D., Draxler, R. R., Munthe, J., and Pacyna, J.: Intercomparison study of atmospheric mercury models: 2 . Modelling results vs. Long-term observations and comparison of country deposition budgets, Sci. Total Environ., 377, 319-333, doi:10.1016/j.scitotenv.2007.01.071, 2007b

Schroeder, W. H. and Munthe, J.: Atmospheric mercury - an overview, Atmos. Environ., 32, 809-822, 1998.

Seigneur, C., Vijayaraghavan, K., Lohman, K., Karamchandani, P., and Scott, C.: Modeling the atmospheric fate and transport of mercury over North America: Power plant emission scenarios, Fuel Process Technol., 85, 441-450, doi:10.1016/j.fuproc.2003.11.001, 2004

Selin, N. E.: Global biogeochemical cycling of mercury: A review, Annu. Rev. Env. Resour., 34, 43-63, doi:10.1146/annurev.environ.051308.084314, 2009.

Selin, N. E. and Jacob, D. J.: Seasonal and spatial patterns of mercury wet deposition in the United States: Constraints on the contribution from North American anthropogenic sources, Atmos. Environ., 42, 5193-5204, doi:10.1016/j.atmosenv.2008.02.069, 2008.

Shah, P., Strezov, V., and Nelson, P. F.: Speciation of mercury in coal-fired power station flue gas, Energ. Fuel, 24, 205-212, doi:10.1021/ef900557p, 2010.

Shepler, B. C. and Peterson, K. A.: Mercury monoxide: a systematic investigation of its ground electronic state, J. Phys. Chem. A, 107, 1783-1787, doi:10.1021/jp027512f, 2003.

Sheu, G. R., Mason, R. P., and Lawson, N. M.: Speciation and distribution of atmospheric mercury over the Northern Chesapeake Bay, in: Chemicals in the Environment: Fate, Impacts, and Remediation, edited by: Lipnick, R. L., American Chemical Society Publication, 223-242, doi:10.1021/bk-2002-0806.ch012, 2002.

Sheu, G. R., Lin, N. H., Wang, J. L., Lee, C. T., Yang, C. F. O., and Wang, S. H.: Temporal distribution and potential sources of atmospheric mercury measured at a high-elevation background station in Taiwan, Atmos. Environ., 44, 2393-2400, doi:10.1016/j.atmosenv.2010.04.009, 2010.

$\mathrm{Si}$, L. and Ariya, P. A. A.: Reduction of oxidized mercury species by dicarboxylic acids $\left(\mathrm{C}_{2}-\mathrm{C}_{4}\right)$ : Kinetic and Product Studies, Environ. Sci. Technol., 42, 5150-5155, doi:10.1021/es800552z, 2008.

Sigler, J. M., Mao, H., and Talbot, R.: Gaseous elemental and reactive mercury in Southern New Hampshire, Atmos. Chem. Phys., 9, 1929-1942, doi:10.5194/acp-9-1929-2009, 2009.

Slemr, F., Ebinghaus, R., Brenninkmeijer, C. A. M., Hermann, M., Kock, H. H., Martinsson, B. G., Schuck, T., Sprung, D., van Velthoven, P., Zahn, A., and Ziereis, H.: Gaseous mercury distribution in the upper troposphere and lower stratosphere observed onboard the CARIBIC passenger aircraft, Atmos. Chem. Phys., 9, 1957-1969, doi:10.5194/acp-9-1957-2009, 2009.

Snider, G., Raofie, F., and Ariya, P. A. A.: Effects of relative humidity and $\mathrm{CO}_{(\mathrm{g})}$ on the $\mathrm{O}_{3}$-initiated oxidation reaction of $\mathrm{Hg}_{(\mathrm{g})}^{0}$ : Kinetic \& product studies, Phys. Chem. Chem. Phys., 10, 56165623, doi:10.1039/B801226A, 2008.

Sommar, J., Gårdfeldt, K., Strömberg, D., and Feng, X.: A kinetic study of the gas-phase reaction between the hydroxyl radical and atomic mercury, Atmos. Environ., 35, 3049-3054, doi:10.1016/S1352-2310(01)00108-X, 2001.

Sommar, J., Andersson, M. E., and Jacobi, H.-W.: Circumpolar measurements of speciated mercury, ozone and carbon monoxide in the boundary layer of the arctic ocean, Atmos. Chem. Phys., 10, 5031-5045, doi:10.5194/acp-10-5031-2010, 2010.

Song, X. J., Cheng, I., and Lu, J.: Annual atmospheric mercury species in downtown Toronto, Canada, J. Environ. Monit., 11, 
660-669, doi:10.1039/b815435j, 2009.

Steen, A. O., Berg, T., Dastoor, A. P., Durnford, D. A., Engelsen, O., Hole, L. R., and Pfaffhuber, K. A.: Natural and anthropogenic atmospheric mercury in the European Arctic: a fractionation study, Atmos. Chem. Phys., 11, 6273-6284, doi:10.5194/acp-11-62732011, 2011.

Steffen, A., Scherz, T., Olson, M., Gay, D., and Blanchard, P.: A comparison of data quality control protocols for atmospheric mercury speciation measurements, J. Environ. Monit., 14, 752765, doi:10.1039/c2em10735j, 2012.

Subir, M., Ariya, P. A., and Dastoor, A. P.: A review of uncertainties in atmospheric modeling of mercury chemistry I. Uncertainties in existing kinetic parameters? Fundamental limitations and the importance of heterogeneous chemistry, Atmos. Environ., 45, 5664-5676, doi:10.1016/j.atmosenv.2011.04.046, 2011.

Subir, M., Ariya, P. A., and Dastoor, A. P.: A review of the sources of uncertainties in atmospheric mercury modeling ii. Mercury surface and heterogeneous chemistry? A missing link, Atmos. Environ., 46, 1-10, doi:10.1016/j.atmosenv.2011.07.047, 2012.

Sumner, A. L., Spicer, C. W., Satola, J., Mangaraj, R., Cowen, K. A., Landis, M. S., Stevens, R. K., and Atkeson, T. D.: Environmental chamber studies of mercury reactions in the atmosphere, in: Dynamics of mercury pollution on regional and global scales, edited by: Pirrone, N. and Mahaffey, K. R., 193-212, Springer, 2005.

Swartzendruber, P. C., Jaffe, D. A., Prestbo, E. M., Weiss-Penzias, P., Selin, N. E., Park, R., Jacob, D. J., Strode, S., and Jaegle, L.: Observations of reactive gaseous mercury in the free troposphere at the Mount Bachelor observatory, J. Geophys. Res.-Atmos., 111, D24302, doi:10.1029/2006JD007415, 2006.

Swartzendruber, P. C., Jaffe, D. A., and Finley, B.: Improved fluorescence peak integration in the Tekran 2537 for applications with sub-optimal sample loadings, Atmos. Environ., 43, 36483651, doi:10.1016/j.atmosenv.2009.02.063, 2009.

ter Schure, A., Caffrey, J., Gustin, M. S., Holmes, C. D., Hynes, A., Landing, B., Landis, M. S., Laudel, D., Levin, L., Nair, U., Jansen, J., Ryan, J., Walters, J., Schauer, J. J., Volkamer, R., Waters, D., and Weiss, P.: An integrated approach to assess elevated mercury wet deposition and concentrations in the southeastern United States, 10th International Conference on Mercury as a Global Pollutant, Halifax, Nova Scotia, Canada, 2011.

Temme, C., Blanchard, P., Steffen, A., Banic, C., Beauchamp, S., Poissant, L., Tordon, R., and Wiens, B.: Trend, seasonal and multivariate analysis study of total gaseous mercury data from the Canadian atmospheric mercury measurement network (CAMNet), Atmos. Environ., 41, 5423-5441, doi:10.1016/j.atmosenv.2007.02.021, 2007.

Timonen, H., Ambrose, J. L., and Jaffe, D. A.: Two new sources of reactive gaseous mercury in the free troposphere, Atmos. Chem. Phys. Discuss., 12, 29203-29233, doi:10.5194/acpd-12-292032012, 2012.

Tossell, J. A.: Calculation of the energetics for oxidation of gasphase elemental $\mathrm{Hg}$ by $\mathrm{Br}$ and $\mathrm{BrO}$, J. Phys. Chem. A, 107, 7804-7808, doi:10.1021/jp030390m, 2003.

Tossell, J. A.: Calculation of the energetics for oligomerization of gas phase $\mathrm{HgO}$ and $\mathrm{HgS}$ and for the solvolysis of crystalline $\mathrm{HgO}$ and $\mathrm{HgS}$, J. Phys. Chem. A, 110, 2571-2578, doi:10.1021/jp056280s, 2006.
Van Loon, L. L., Mader, E., and Scott, S. L.: Reduction of the aqueous mercuric ion by sulfite: UV spectrum of $\mathrm{HgSO}_{3}$ and its intramolecular redox reaction, J. Phys. Chem. A, 104, 1621-1626, doi:10.1021/jp994268s, 2000.

Vijayaraghavan, K., Karamchandani, P., Seigneur, C., Balmori, R., and Chen, S.-Y.: Plume-in-grid modeling of atmospheric mercury, J. Geophys. Res., 113, D24305, doi:10.1029/2008JD010580, 2008.

Wan, Q., Feng, X. B., Lu, J., Zheng, W., Song, X. J., Li, P., Han, S. J., and $\mathrm{Xu}, \mathrm{H} .:$ Atmospheric mercury in Changbai mountain area, Northeastern China II. The distribution of reactive gaseous mercury and particulate mercury and mercury deposition fluxes, Environ. Res., 109, 721-727, doi:10.1016/j.envres.2009.05.006, 2009a.

Wan, Q., Feng, X. B., Lu, J. L., Zheng, W., Song, X. J., Han, S. J., and $\mathrm{Xu}, \mathrm{H}$.: Atmospheric mercury in Changbai Mountain area, Northeastern China I. The seasonal distribution pattern of total gaseous mercury and its potential sources, Environ. Res., 109, 201-206, doi:10.1016/j.envres.2008.12.001, 2009b.

Wang, Y. J., Duan, Y. F., Yang, L. G., Zhao, C. S., and Xu, Y. Q.: Mercury speciation and emission from the coal-fired power plant filled with flue gas desulfurization equipment, Can. J. Chem. Eng., 88, 867-873, doi:10.1002/cjce.20331, 2010.

Weiss-Penzias, P., Jaffe, D., Swartzendruber, P., Hafner, W., Chand, D., and Prestbo, E.: Quantifying asian and biomass burning sources of mercury using the $\mathrm{Hg} / \mathrm{CO}$ ratio in pollution plumes observed at the mount bachelor observatory, Atmos. Environ., 41, 4366-4379, doi:10.1016/j.atmosenv.2007.01.058, 2007.

Weiss-Penzias, P., Gustin, M. S., and Lyman, S. N.: Observations of speciated atmospheric mercury at three sites in Nevada: Evidence for a free tropospheric source of reactive gaseous mercury, J. Geophys. Res.-Atmos., 114, D14302, doi:10.1029/2008JD011607, 2009.

Weiss-Penzias, P. S., Gustin, M. S., and Lyman, S. N.: Sources of gaseous oxidized mercury and mercury dry deposition at two Southeastern U.S. sites, Atmos. Environ., 45, 4569-4579, doi:10.1016/j.atmosenv.2011.05.069, 2011.

Wu, C. L., Cao, Y., Dong, Z., Cheng, C., Li, H., and Pan, W.: Evaluation of mercury speciation and removal through air pollution control devices of a 190 MW boiler, J. Environ. Sci., 22, $277-$ 282, doi:10.1016/S1001-0742(09)60105-4, 2010.

Wu, Y., Streets, D. G., Wang, S. X., and Hao, J. M.: Uncertainties in estimating mercury emissions from coal-fired power plants in China, Atmos. Chem. Phys., 10, 2937-2946, doi:10.5194/acp10-2937-2010, 2010.

Xiao, Z. F., Stromberg, D., and Lindqvist, O.: Influence of humic substances on photolysis of divalent mercury in aqueous solution, Water Air Soil Poll., 80, 789-798, doi:10.1007/BF01189730, 1995.

Yatavelli, R. L. N., Fahrni, J. K., Kim, M., Crist, K. C., Vickers, C. D., Winter, S. E., and Connell, D. P.: Mercury, $\mathrm{PM}_{2.5}$ and gaseous co-pollutants in the Ohio River valley region: Preliminary results from the Athens supersite, Atmos. Environ., 40, 6650-6665, doi:10.1016/j.atmosenv.2006.05.072, 2006.

Zhang, L.: A size-segregated particle dry deposition scheme for an atmospheric aerosol module, Atmos. Environ., 35, 549-560, doi:10.1016/S1352-2310(00)00326-5, 2001.

Zhang, L., Brook, J. R., and Vet, R.: A revised parameterization for gaseous dry deposition in air-quality models. Atmos. Chem. 
Phys., 3, 1777-1804, doi:10.5194/acpd-3-1777-2003, 2003.

Zhang, L., Blanchard, P., Johnson, D., Dastoor, A., Ryzhkov, A., Lin, C. J., Vijayaraghavan, K., Gay, D., Holsen, T. M., Huang, J., Graydon, J. A., St Louis, V. L., Castro, M. S., Miller, E. K., Marsik, F., Lu, J., Poissant, L., Pilote, M., and Zhang, K. M.: Assessment of modeled mercury dry deposition over the Great Lakes region. Environ. Poll., 161, 272-283, doi:10.1016/j.envpol.2011.06.003, 2012.
Zhang, Y., Jaeglé, L., van Donkelaar, A., Martin, R. V., Holmes, C. D., Amos, H. M., Wang, Q., Talbot, R., Artz, R., Brooks, S., Luke, W., Holsen, T. M., Felton, D., Miller, E. K., Perry, K. D., Schmeltz, D., Steffen, A., Tordon, R., Weiss-Penzias, P., and Zsolway, R.: Nested-grid simulation of mercury over North America, Atmos. Chem. Phys. Discuss., 12, 2603-2646, doi:10.5194/acpd-12-2603-2012, 2012. 